\title{
Regional Groundwater Quality Management through Hydrogeological Modeling in LCC, West Faisalabad, Pakistan
}

\author{
Aamir Shakoor, ${ }^{1}$ Zahid Mahmood Khan, ${ }^{1}$ Muhammad Arshad, ${ }^{2}$ Hafiz Umar Farid, \\ Muhammad Sultan, ${ }^{1}$ Muhammad Azmat, ${ }^{3}$ Muhammad Adnan Shahid, ${ }^{4}$ and Zafar Hussain ${ }^{5}$ \\ ${ }^{1}$ Department of Agricultural Engineering, Bahauddin Zakariya University, Multan, Pakistan \\ ${ }^{2}$ Department of Irrigation and Drainage, University of Agriculture, Faisalabad, Pakistan \\ ${ }^{3}$ Geo-Informatics Engineering, National University of Sciences and Technology (NUST), Islamabad, Pakistan \\ ${ }^{4}$ Water Management Research Center, University of Agriculture, Faisalabad, Pakistan \\ ${ }^{5}$ Department of Forestry and Range Management, Bahauddin Zakariya University, Multan, Pakistan
}

Correspondence should be addressed to Hafiz Umar Farid; farid_vjr@yahoo.com

Received 8 May 2017; Revised 11 August 2017; Accepted 23 August 2017; Published 19 October 2017

Academic Editor: Pedro Ávila-Pérez

Copyright (C) 2017 Aamir Shakoor et al. This is an open access article distributed under the Creative Commons Attribution License, which permits unrestricted use, distribution, and reproduction in any medium, provided the original work is properly cited.

\begin{abstract}
The intensive abstraction of groundwater is causing a number of problems such as groundwater depletion and quality deterioration. To manage such problems, the data of 256 piezometers regarding groundwater levels and quality were acquired for the period of 2003 to 2012 in command area of Lower Chenab Canal (LCC), West Faisalabad, Pakistan. MODFLOW and MT3D models were calibrated for the period of 2003-2007 and validated for years 2008-2012 with respect to observed groundwater levels and quality data, respectively. After the successful calibration and validation, two pumping scenarios were developed up to year 2030: Scenario I (increase in pumping rate according to the historical trend) and Scenario II (adjusted canal water supplies and groundwater patterns). The predicted results of Scenario I revealed that, up to year 2030, the area under good quality groundwater reduced significantly from 50.35 to $28.95 \%$, while marginal and hazardous groundwater quality area increased from 49.65 to $71.06 \%$. Under Scenario II, the good quality groundwater area increased to $6.32 \%$ and $12.48 \%$ area possesses less hazardous quality of groundwater. It was concluded that the canal water supply should shift from good quality aquifer zone to poor quality aquifer zone for proficient management of groundwater at the study area.
\end{abstract}

\section{Introduction}

In Pakistan, groundwater is the second largest source of irrigated agriculture because of the arid climatic conditions $[1,2]$. The reliance on groundwater has significantly increased during the past two decades to meet the food and fiber requirements of growing population [3]. Furthermore, the surface irrigation system has high degree of conveyance and application water losses. Thus, the system operates at an efficiency of less than $40 \%$ that meets only less than $40 \%$ of the crop water requirements [4]. The provision of irrigation water from other sources such as groundwater is indispensable for potential productivity [5]. The growth rate of private tube wells has increased significantly at the rate of $60 \%$ in Punjab province from 1991 to 2000. About 1.20 million tube wells of capacity ranging from 0.015 to $0.056 \mathrm{~m}^{3} / \mathrm{sec}$ have been installed in Pakistan for irrigation at depth of $30-85 \mathrm{~m}$ having diameter of $15-30 \mathrm{~cm}$, out of which $86 \%$ tube wells are installed in Punjab [6]. The farmers of tail ends of the distributaries and watercourses are forced to rely heavily on groundwater, particularly where canal water supplies are constrained. Without groundwater availability, not only Punjab but the whole country would face a severe water shortage that leads to food shortages as Punjab produces more than $90 \%$ of total grains [7]. However, the unchecked abstraction of groundwater has created serious negative concerns in terms of lowering water table and saltwater intrusion that may lead to the issues of sustainability of usable groundwater resources. As a result of saline groundwater intrusion, about 200 public tube wells initially installed in the fresh groundwater zone of 
Punjab and Sindh provinces had been abandoned [8]. Shah [9] reported similar problems existed in most of the irrigated regions of the world; those were further increasing rapidly and negatively affecting agricultural productivity.

There are wide spatial and temporal variations in groundwater quality in the Indus basin, which is due to the pattern of groundwater movement in the aquifer [10]. The belt of fresh groundwater is generally available near the main rivers and canal on account of high recharge of fresh seepage water. But, then, the quality of groundwater changes to unfit as laterally away from the rivers $[5,11]$. The continuous and intensive use of groundwater for irrigation is adding plenty of salts causing secondary salinization because groundwater generally has more salts than canal water. Bakhsh and Awan [12] reported that application of groundwater having total dissolved solids (TDS) of $1000 \mathrm{mgL}^{-1}$ up to a soil depth $370 \mathrm{~mm}$ changed the top $300 \mathrm{~mm}$ depth of nonsaline into a saline soil that impaired crop productivity. In many agricultural areas of Pakistan, the usage of poor quality tube well water for irrigation is considered as one of the major causes of salinity and, consequently, lower food productivity [13]. According to an estimate in Pakistan, the secondary salinization degraded the crop land which reduced the production potential of major crops by $25 \%$, valued at an estimated loss of US \$250 million/year [14]. Low quality water and soil salinity can affect plant growth and soil structure in several ways, directly and indirectly [15].

Thus, the assessment of groundwater quality is important to ensure the safe use of these resources on a sustainable basis. Groundwater models are most widely used tools for efficient management of precious groundwater resources and to predict different future scenarios [16]. Different groundwater modeling codes are available, each with their own capabilities, operational characteristics, and limitations such as PMWIN, FEFLOW, SVFlux, and GWVistas. But the most extensively used three-dimensional groundwater flow model among the available models is PMWIN (Processing MODFLOW for Window) $[17,18]$. Its popularity has continued, in part due to the modularity of the program, resulting ability, and user friendly interface [19]. It uses a block-centered finitedifference scheme for saturated zone. The advantages of PMWIN include numerous facilities for data preparation, easy exchange of data in standard form, extended worldwide experience, continuous development, availability of source code, and relatively low price or being freely available [20]. A number of research studies have been conducted regarding application of modeling approach for groundwater management in different part of the world. Moeck et al. [21] developed a 3D groundwater model for simulating existing and proposed water management strategies as a tool to ensure the utmost security for drinking water in Basel, Switzerland. Gebreyohannes et al. [22] developed regional groundwater flow model for Geba Basin, northern Ethiopia, and reported that none of the hydrogeological formations can be exploited for large-scale groundwater exploitation. Rahmawati et al. [23] conducted research to study saltwater intrusion from 1995 to 2108 in Semarang city based on well log data and MODFLOW numerical model was used. For salt intrusion projection in the future, the sea level rise projection also was conceived. Kori et al. [17] linked groundwater flow model (MODFLOW) with solute transport model (MT3D), and several simulation runs were carried out after successful calibration of model for two sampled sites located at JRS-57 and JRS60 tube wells at Nawabshah-Pakistan. Carretero et al. [24] applied groundwater modeling technique to study the impact of a possible rise of $1 \mathrm{~m}$ in sea level against the low-lying coast of Partido de La Costa, Argentina. Similarly, Abu-el-Shar and Hatamleh [25] simulated the groundwater model (PMWIM) for the Azraq Basin, Jordan, to manage groundwater. The large number of latest research papers-Asoka et al. [26], Galitskaya et al. [27], Kambale et al. [28], Abdullah and Morteza [29], and Durand et al. [30]—dealing with groundwater management using modeling techniques were published is a testimony to the important role played by the models.

Therefore, the assessment of groundwater quality through modeling is important to ensure the safe use of these resources on a sustainable basis. If unchecked pumping of groundwater continues to remain in the study area, the irrigation tube wells would not be able to lift water at their present quality. Hence, there is a dire need to investigate the impact of groundwater flow conditions and overexploitation on groundwater quality. Thus, the followings were the two main objectives of the current study: (1) to develop a regional hydrogeological groundwater flow model and observe its future trend and (2) to formulate groundwater management strategy for its proficient utilization.

\section{Material and Methods}

2.1. Study Area. The research study was carried out in the command area of Lower Chenab Canal (LCC), West Faisalabad, Pakistan, having longitude of $73.85^{\circ}$ to $72.18^{\circ}$ (E) and latitude of $32.32^{\circ}$ to $30.85^{\circ}(\mathrm{N})$ (Figure 1). The site has gross command area of $1.16 \mathrm{Mha}$ and culturable command area of $0.98 \mathrm{Mha}$, respectively. It falls in rice-wheat agroecological zone of province Punjab, Pakistan. It is comprised of vast canal network such as main canals, branch canals, and minor distributaries. The River Chenab and Gugera Branch Canals are located at the northwest and southeast side, respectively. Similarly, Qadirabad-Baluki Link Canal is located in the northeast side and Trimmu-Sidhnai Link Canal is present in the southwest side of the study area (Figure 2).

2.2. Climatic. The summer season starts from April and continues till October. The temperature varies in the range of 21 to $51^{\circ} \mathrm{C}$ during the summer season. Similarly, the winter season starts from October and lasts till April with temperature ranges of 1 to $27^{\circ} \mathrm{C}$. The average annual precipitation was estimated to be $439 \mathrm{~mm}$. The ten-year average value of $\mathrm{ET}_{o}$ was $1413 \mathrm{~mm} /$ year.

2.3. Hydrogeological Conditions. Lithology of aquifer system in the study area has different classification according to different textural characteristics. The surface soil textures are largely fine and moderately medium with good permeability properties. The aquifers of study area were formed as a result of sediment deposition due to flat topography. These 


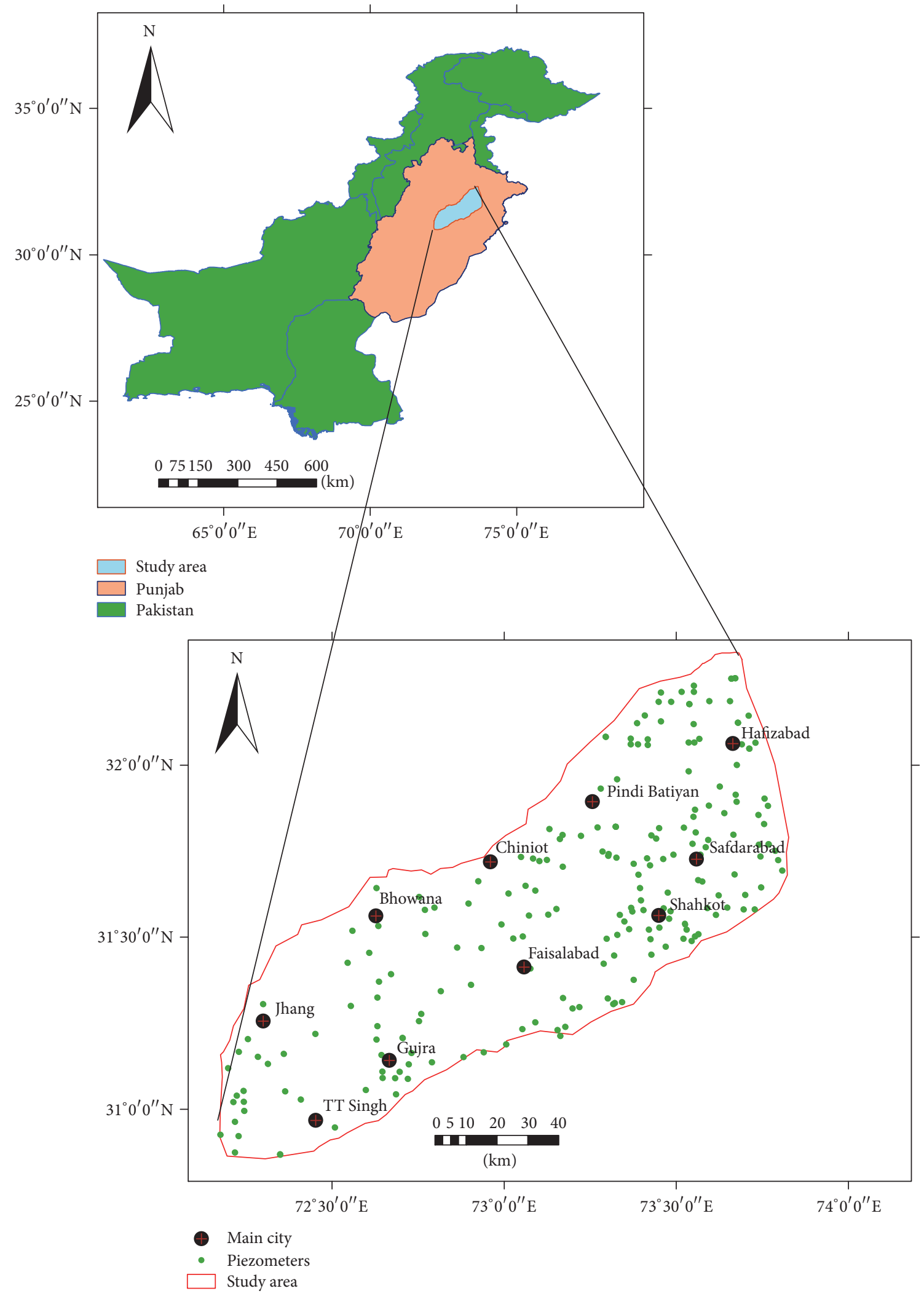

FIGURE 1: Geographical location of study area. 


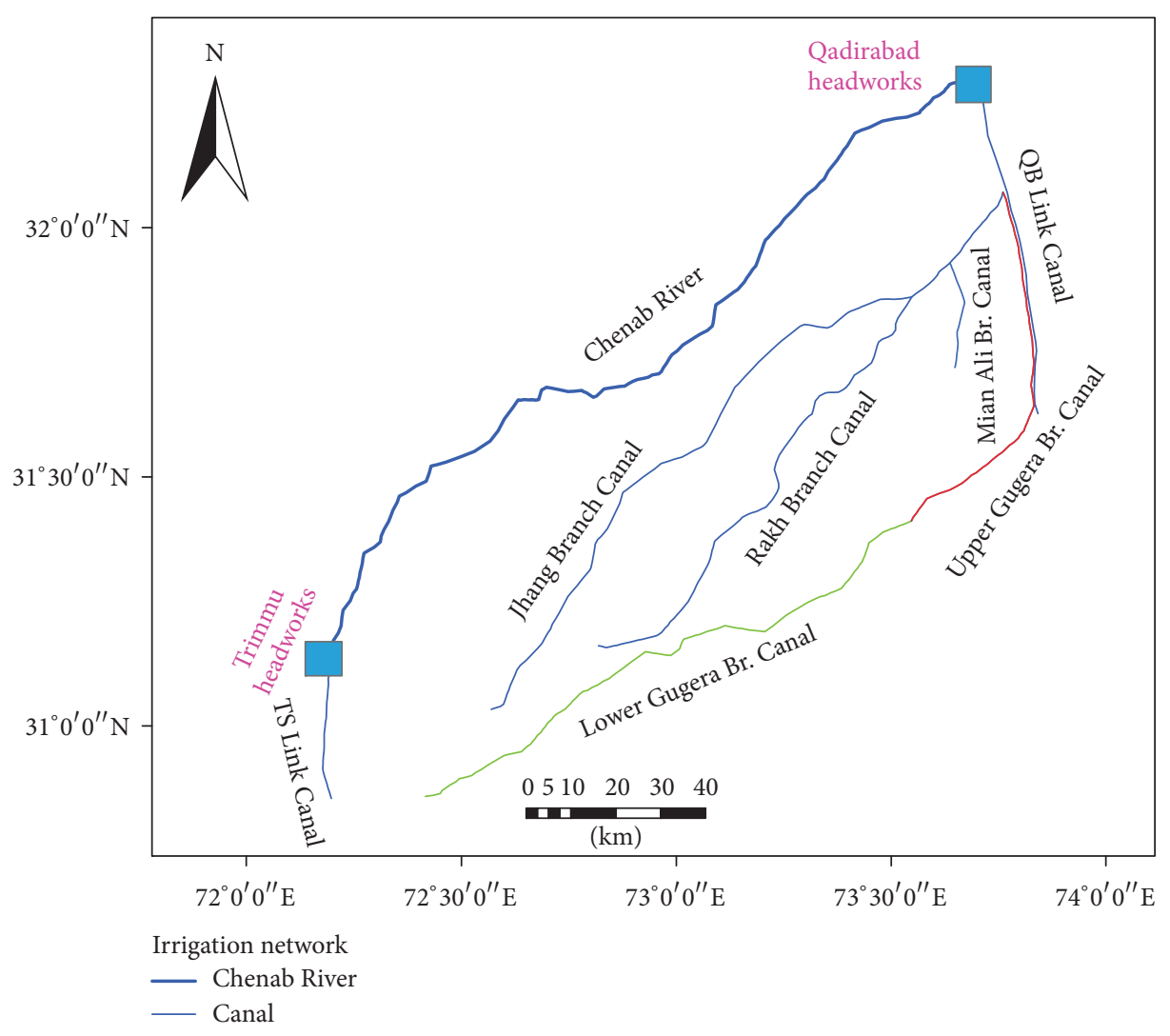

Figure 2: Canal network of the study area.

sediments were carried by the river waters from the vast alluvial basin of rivers as a result of materials washed down from Himalayan Mountain. In general, like other aquifers in Punjab, the aquifers of study area are unconfined. The groundwater levels in the year 2012 were present in the range of 145 to $205 \mathrm{~m}$ (Figure 3). The groundwater level was higher in the upper part and gradually decreased towards the lower side, which means that the groundwater flow was from upper to lower side.

The good quality groundwater is present in the northern part whereas poor quality groundwater is in the southern part of the study area. The average spatial variation of measured groundwater TDS in the entire study area for the year 2012 is given in Figure 4. A calibrated TDS meter (TDS-98302) was used to measure the TDS of groundwater with an accuracy of $\pm 2 \%$. The calibration of TDS meter was accomplished in the standard solution in the Water Quality and Environment Laboratory, Department of Irrigation and Drainage, University of Agriculture, Faisalabad. The measured TDS values indicated that almost half of the aquifer of the study area has marginal to hazardous quality of groundwater. A $30 \mathrm{~km}$ wide strip along the Chenab River had groundwater of good quality, whereas hazardous quality groundwater existed in $20 \mathrm{~km}$ wide strip at a distance of $40 \mathrm{~km}$ away from the Chenab River. The groundwater quality zones of fresh and saline water were formulated according to criteria developed by WAPDA [31] for irrigation water quality (good: TDS < $1000 \mathrm{mg} / \mathrm{L}$; marginal: TDS of 1000-1700 mg/L; and hazardous: TDS > $1700 \mathrm{mg} / \mathrm{L}$ ),
Shakoor et al. [6]. The northern and northwestern part of the study area (along Chenab River) contained good quality groundwater. The marginal and hazardous quality was laid in the southern part of the study area.

The annual water balance of the whole study area from the year 2003 to the year 2012 is shown in Figure 5. The water balance describes the volume of water entering, subtraction, and net storage in the aquifer system. The water entering parameters are recharge and river leakage, while subtraction parameters are wells and ET. The positive storage term showed that volume of water extracted from the aquifer was more than the recharge which means crop water demand was fulfilled from aquifer storage and vice versa. The storage in the aquifer in 2003 and 2012 was -444.5 and 326.6 MCM, respectively, clearly indicating the replenishment of aquifer in 2012. Similarly, the volume of water withdrawn through tube wells increased from 3298 to 3759 MCM from years 2003 to 2012, respectively, also showing increased demand of groundwater.

2.4. Model Selection. PMWIN 5.3 (Processing MODFLOW for Window) was used in this research. It is a simulation system based on the modular three-dimensional finitedifference technique for modeling groundwater flow and contamination in groundwater with a wide range of natural systems. PMWIN is used widely throughout the world and it was applied in many groundwater modeling applications $[17,23,25]$. 


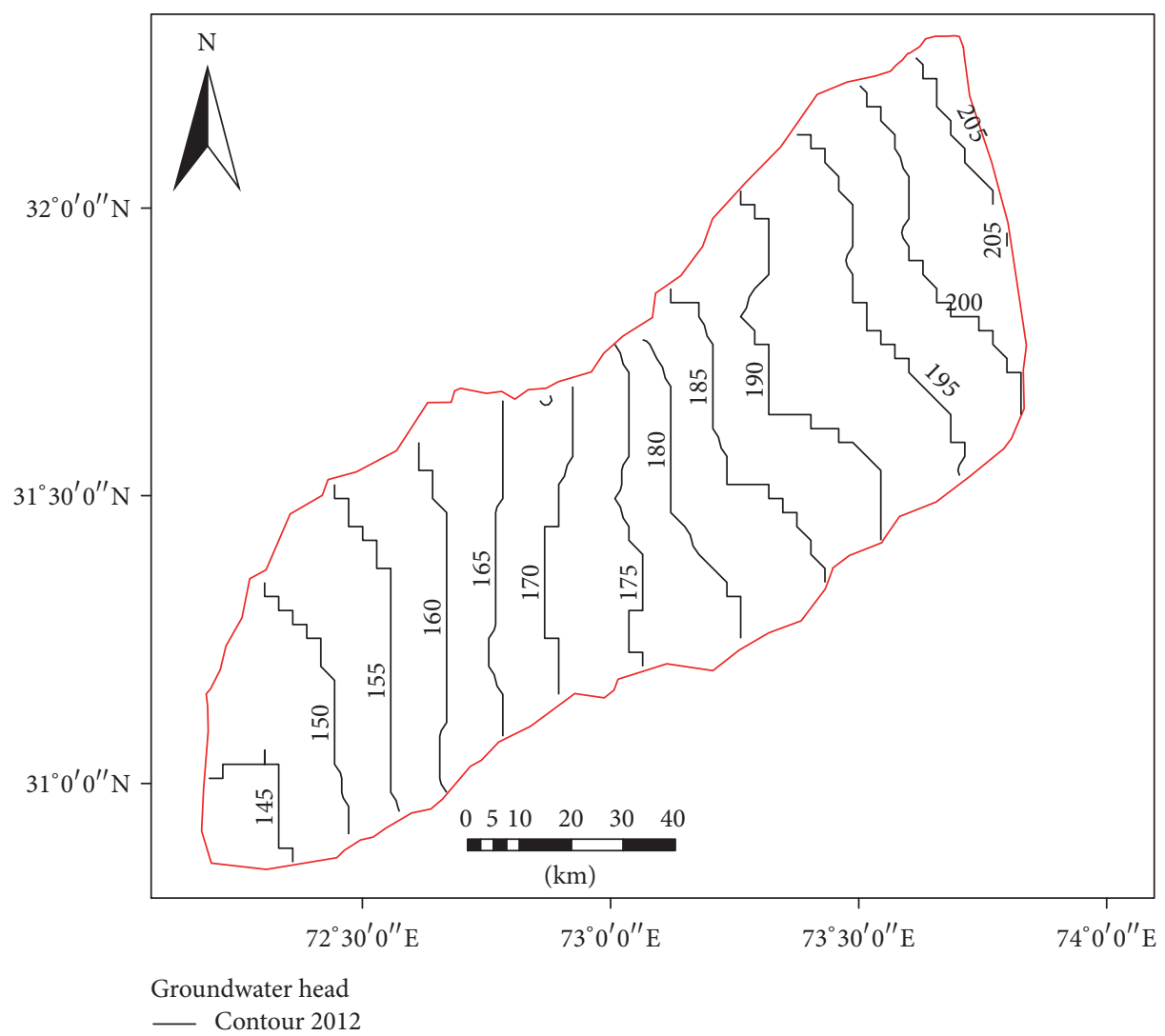

FIGURE 3: Spatial variation in measured groundwater levels for the year 2012.

2.5. Model Input and Calibration. The MODFLOW and MT3D models are packages of PMWIN 5.3. They were calibrated with respect to observed groundwater level and quality data, respectively, using inverse modeling method. The data of 256 piezometers regarding groundwater level and quality were acquired from the Department of Land and Reclamation, Faisalabad, for the period from 2003 to 2012 to achieve the model calibration and validation (Figure 1). The piezometer wells have maximum depths of $55 \mathrm{~m}$. The depth of piezometers varied at some location depending upon the water table conditions. The piezometer wells have diameters of $5 \mathrm{~cm}$ and strainer lengths of $3 \mathrm{~m}$.

The model area had a square geometry and the whole area was divided into 76 columns and 76 rows. The total number of cells was of 5776 cells. Each square cell has a dimension of $2.5 \mathrm{~km} \times 2.5 \mathrm{~km}$. The model area had 3653 inactive cells, which were outside the boundary of the study area, while the model area had 2123 active cells located within the boundary of study area. The cell size of $2.5 \mathrm{~km} \times 2.5 \mathrm{~km}$ $\left(6.25 \mathrm{~km}^{2}\right)$ was also used for groundwater modeling studies by Al-Fatlawi [32] in Umm Er Radhuma, the Western Desert, Iraq, and by Khan et al. [33] in Rechna Doab. Abu-el-Shar and Hatamleh [25] developed groundwater model for the Azraq Basin and the biggest cell size of $8.69 \mathrm{~km}^{2}$ was selected. Similarly, Schoups et al. [34] used cell size of $2 \mathrm{~km} \times 2 \mathrm{~km}$ to calibrate groundwater model of the Yaqui Valley, having
$6800 \mathrm{~km}^{2}$ irrigated agricultural region located along the Sea of Cortez in Sonora, Mexico.

Lithology of aquifer system in the study area was obtained from the Water and Power Development Authority (WAPDA) [31]. The soils have different classification according to different textural characteristics. The surface soil textures are largely fine and moderately medium, with good permeability properties. The areas of 4451.3 (38.48\%), 4987.3 (43.08\%), 1621 (14\%), $464.1(4 \%)$, and $52.3 \mathrm{~km}^{2}$ (0.45\%) have soil texture of fine, moderately medium, medium, moderately course, and course, respectively. The aquifer of the study area was defined with four different layers depending upon their lithological data [31]. The spatial domain represented in the model consisted of four layers (0-7, 7-30, 30-90, and $90 \mathrm{~m}$ to bedrock). The horizontal $\left(K_{h}\right)$ and vertical $\left(K_{v}\right)$ hydraulic conductivities have large variation from one to the other side of the study area (Table 1). The minimum and maximum values of $1-265 \mathrm{~m} /$ day and $1-15 \mathrm{~m} /$ day, respectively, for horizontal and vertical hydraulic conductivities were used in the model, as majority of the tube wells were installed in second layer because $80 \%$ part of study area has $K_{h}$ in the range of $70-100 \mathrm{~m} /$ day. The similar range of values for hydraulic conductivity within Punjab province domain was used by Jehangir et al. [35]; Ahmad [36]; Arshad [37]; and Khan et al. [33]. The specific storage values for layer 1 ranged as $0.0001-0.001 \mathrm{~m}^{-1}$ and for the remaining layers the values 
TABLE 1: Lithological data of all layers.

\begin{tabular}{|c|c|c|c|c|c|c|c|c|}
\hline $\begin{array}{l}\text { Subsurface } \\
\text { layers }\end{array}$ & $\begin{array}{c}K_{h} \\
\text { (m/day) }\end{array}$ & $\begin{array}{c}\% \\
\text { area }\end{array}$ & $\begin{array}{c}K_{v} \\
\text { (m/day) }\end{array}$ & $\begin{array}{c}\% \\
\text { area }\end{array}$ & $\begin{array}{c}\text { Specific storage } \\
\left(\mathrm{m}^{-1}\right)\end{array}$ & $\begin{array}{c}\% \\
\text { area }\end{array}$ & Specific yield & $\begin{array}{c}\% \\
\text { area }\end{array}$ \\
\hline \multirow{3}{*}{ (Layer 1) } & $1-15$ & 20 & $>0-1$ & 80 & $1 E-4-5 E-4$ & 40 & $0.05-0.013$ & 15 \\
\hline & $15-70$ & 60 & $1-5$ & 10 & $5 E-4-6 E-4$ & 25 & $0.013-0.17$ & 60 \\
\hline & $70-160$ & 20 & $5-15$ & 10 & $6 E-4-1 E-3$ & 35 & $0.17-0.25$ & 25 \\
\hline \multirow{3}{*}{ (Layer 2) } & $1-70$ & 10 & $>0-2$ & 50 & $1 E-5-2 E-4$ & 5 & $0.05-0.15$ & 10 \\
\hline & $70-100$ & 80 & $4-10$ & 25 & $3 E-4-1 E-3$ & 15 & $0.2-0.25$ & 80 \\
\hline & $100-165$ & 10 & $10-15$ & 25 & $2 E-4-3 E-4$ & 80 & $0.15-0.2$ & 10 \\
\hline \multirow{3}{*}{ (Layer 3) } & $20-80$ & 20 & $>0-2$ & 50 & $1 E-5-2 E-4$ & 5 & - & - \\
\hline & $80-120$ & 30 & $4-10$ & 25 & $3 E-4-1 E-3$ & 15 & - & - \\
\hline & $120-265$ & 20 & $10-15$ & 25 & $2 E-4-3 E-4$ & 80 & - & - \\
\hline \multirow{3}{*}{ (Layer 4) } & $20-80$ & 20 & $>0-2$ & 50 & $1 E-5-2 E-4$ & 5 & - & - \\
\hline & $80-120$ & 30 & $4-10$ & 25 & $3 E-4-1 E-3$ & 15 & - & - \\
\hline & $120-265$ & 20 & $10-15$ & 25 & $2 E-4-3 E-4$ & 80 & - & - \\
\hline
\end{tabular}

$K_{h}$ : horizontal hydraulic conductivity. $K_{v}$ : vertical hydraulic conductivity.

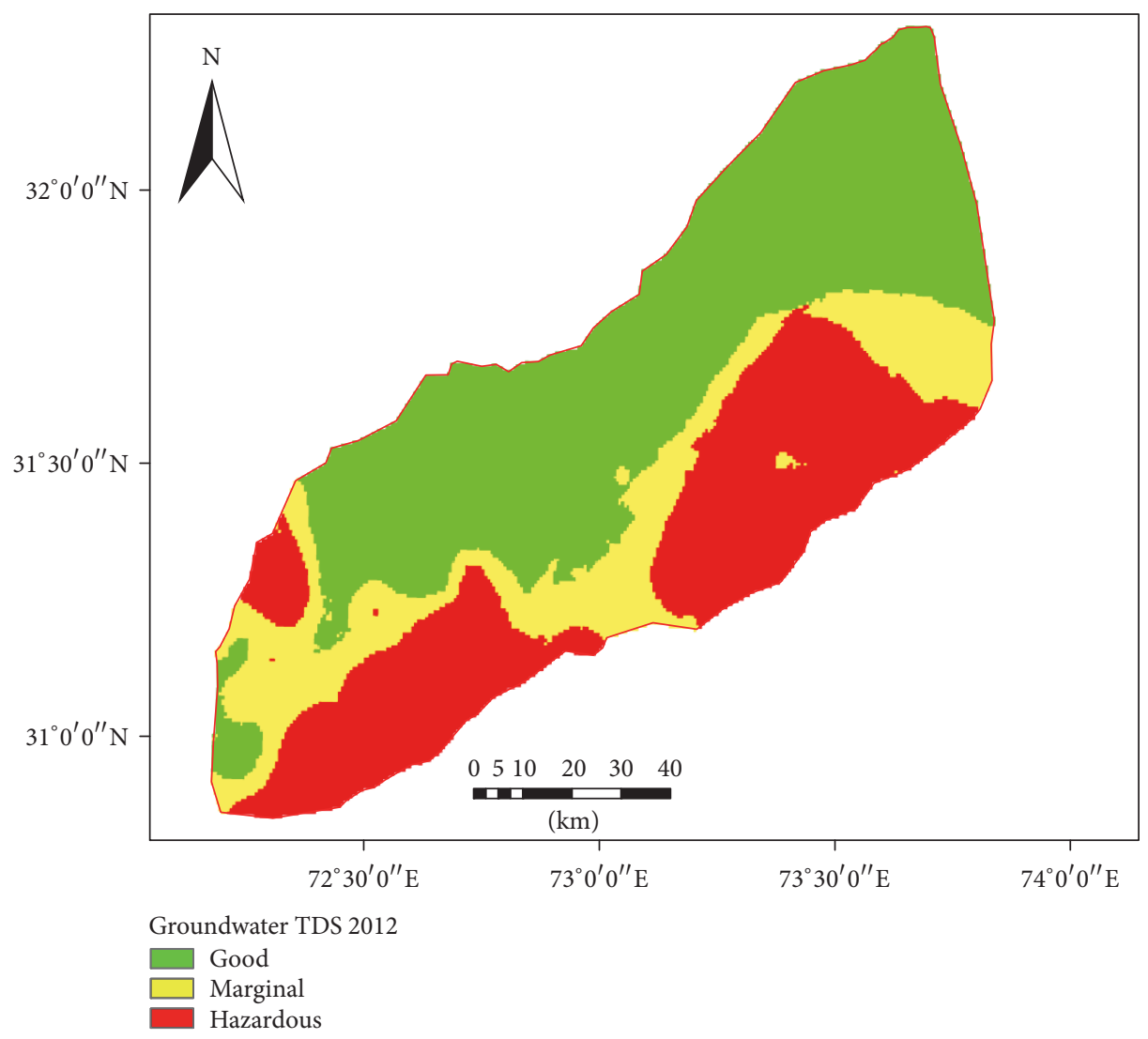

FIGURE 4: Spatial variations of measured groundwater TDS in the year 2012.

of $0.00001-0.0003 \mathrm{~m}^{-1}$ were used. The values of specific yield for layer 1 ranged as $00.05-0.25$ and for the remaining layers the values of $0.05-0.20$ were used. The effective porosity of 0.25 was given to all layers [31]. The simulation time unit "days" and simulation flow type "transient" was selected. Two stress periods in each year were considered to represent the Kharif and Rabi seasons having 183 and 182 days, respectively, with six time steps in each stress period, as there are two main cropping seasons based on agroclimatic conditions in
Pakistan, Kharif and Rabi. Kharif starts from June and July and goes to October and November, while the Rabi season starts from September and October and continues to April and May.

The cumulative evapotranspiration during a period (Kharif or Rabi) was divided by its duration in days and thus the evapotranspiration rate per day was calculated using CROPWAT. The evapotranspiration rates of 0.006 and $0.003 \mathrm{~m} /$ day were used for odd (Kharif) and even (Rabi) 


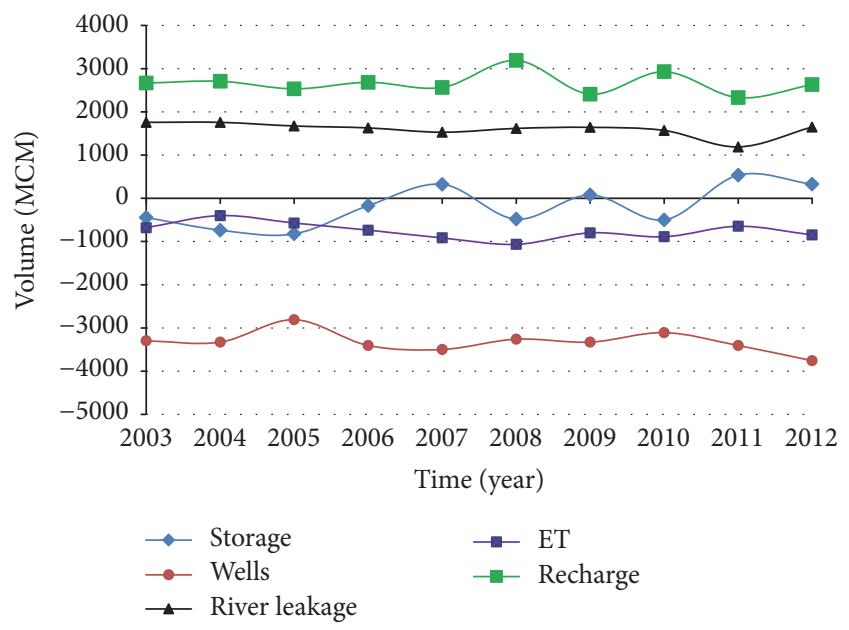

FIGURE 5: Water balance for the years 2003 to 2012.

stress periods, respectively, throughout the model stress periods for model calibration. The recharge package was used to simulate spatial distribution of recharge water at field from rainfall and irrigation to the groundwater system. The minimum and maximum recharge values from 0.00065 to $0.0013 \mathrm{~m} /$ day were used for odd (Kharif) stress periods, whereas values from 0.00026 to $0.0005 \mathrm{~m} /$ day were used for even (Rabi) stress periods. The river package was used to simulate the flow between an aquifer and surface-water features such as rivers, canals, lakes, and reservoir. The hydraulic features, such as canal length, bed width, fullsupply level, hydraulic conductance, and discharge of the canals of the study area, were used. The recharge flux was computed by the model through the canal system. The net groundwater demand was calculated by subtracting the net canal water supplies from net crop water requirement. After providing all the input data, the calibration process was started. In this calibration process, input parameters such as recharge, pumping rate, and hydraulic conductivities were adjusted in MODFLOW.

2.6. Solute Transport Model. The MT3D numerical model with PMWIN 5.3 user interface was used to simulate advection and dispersion contaminants in the three-dimensional groundwater flow system of the study area. The MT3D simulated groundwater flow by numerically solving the groundwater flow and solute transport equations. The partial differential equation describing the three-dimensional transport of dissolved solutes in the groundwater [38] can be written in

$$
\frac{\partial}{\partial x_{i}}\left(D_{i} \frac{\partial C}{\partial X_{i}}\right)-\frac{\partial}{\partial x_{i}}\left(v_{i} C\right) \pm \frac{q_{s}}{\theta} c_{s}+\sum_{k=1}^{N} R_{k}=\frac{\partial C}{\partial t},
$$

where $C$ is the concentration of contaminants dissolved in groundwater $\left[\mathrm{ML}^{-3}\right], x_{i}$ is the distance along the respective Cartesian coordinate axis $[\mathrm{L}], D_{i}$ is the hydrodynamic dispersion coefficient $\left[\mathrm{L}^{2} \mathrm{~T}^{-1}\right], v_{i}$ is the seepage or linear pore water velocity $\left[\mathrm{LT}^{-1}\right], q_{s}$ is the volumetric flux of water per unit volume of aquifer representing sources (positive) and sinks (negative) $\left[\mathrm{T}^{-1}\right], C_{s}$ is the concentration of sources or sinks $\left[\mathrm{ML}^{-3}\right], \sum_{K=1}^{N} R_{k}$ is the chemical reaction term $\left[\mathrm{ML}^{-3} \mathrm{~T}^{-1}\right]$, and $t$ is time [T].

The calibration of MT3D was achieved by adjusting the values of advection and dispersion values. Advection depicts mass transport basically due to the bulk flow of water in which the mass is dissolved or movement of solute as a result of groundwater flow. Advection is the dominant process of solute transport due to groundwater flow. For a given time step, the movement of solutes due to advection was simulated using the corresponding field velocity which was computed by the calibrated MODFLOW model and the effective porosity of the aquifer. MXPART of maximum 1300000 particles was allowed in a simulation while the value PERCEL (Courant number or number of cells in any particle) was selected as 0.79 . It was allowed to move in any direction within one transport step and generally ranged from 0.5 to 1 [39]. The default values of the remaining parameters were used for MT3D model.

The longitudinal dispersivity $\left(\alpha_{L}\right)$ and transverse dispersivity $\left(\alpha_{T}\right)$ are required to estimate dispersive transport of the solute. The dispersivity is a characteristic property of the porous medium that describes the spreading of the solute in a medium. Longitudinal dispersivity is used when the spreading of solute is in the direction of bulk flow, whereas the transverse dispersivity is the perpendicular (vertical and horizontal) spreading of solute to the direction of bulk flow. The longitudinal dispersivity $\left(\alpha_{L}\right)$ was computed from molecular diffusion and local dispersion coefficient based on heterogeneity of the medium $[40,41]$ as given in

$$
\alpha_{L}=\left(\frac{D_{d}}{v}+\frac{D_{L}}{v}\right)+A_{L},
$$

where $\alpha_{L}$ is longitudinal dispersivity $(\mathrm{cm}), D_{d}$ is coefficient of molecular diffusion $\left(16 \times 10^{-6} \mathrm{~cm}^{2} / \mathrm{s}\right), V$ is velocity of flow $(6.8$ $\left.\times 10^{-6} \mathrm{~cm} / \mathrm{s}\right), D_{L}$ is dispersion coefficient $\left(30 \times 10^{-6} \mathrm{~cm}^{2} / \mathrm{s}\right)$, and $A_{L}$ is asymptotic longitudinal dispersivity $(500 \mathrm{~cm})$. Asymptotic longitudinal dispersivity is due to heterogeneity of the medium, mainly dependent on the variance of the $\log$ transformed conductivity and correlation length in the mean direction of flow. As no field data were available for solute transport in aquifer media, the value of $A_{L}$ was adopted as $500 \mathrm{~cm}$ after [42]. The Peclet number, $P_{e}=$ $\Delta x / \alpha_{L}$, was calculated to measure the relative significance of advection and dispersion in the study area, where $\Delta x$ is the size of a cell equal to $2500 \mathrm{~m}$. The unitless Peclet number is usually used to decide the dominant factor in solute transport among advection and dispersion [43]. After the successful calibration of both models (MODFLOW and MD3D) for years 2003-2007, the models validated for the years 2008-2012 and two future scenarios were simulated.

2.7. Future Scenarios. The model prediction was accomplished in order to investigate the response of the model for two future scenarios regarding the pumping rate up to year 2030. It was assumed that there will be no uncertain change or tragedy in climate and irrigation system. In Scenario I, 
TABLE 2: Statistical analysis of the field and modeled data.

\begin{tabular}{|c|c|c|c|}
\hline \multirow[b]{2}{*}{ Parameters } & \multirow[b]{2}{*}{ Formula } & \multicolumn{2}{|c|}{ Results } \\
\hline & & $\begin{array}{l}\text { MODFLOW } \\
\text { (m) }\end{array}$ & $\begin{array}{l}\text { MT3D } \\
(\mathrm{mg} / \mathrm{L})\end{array}$ \\
\hline Mean error & $\mathrm{ME}=\frac{1}{n} \sum_{i=1}^{n}\left(h_{o}-h_{s}\right)$ & -1.10 & 19.5 \\
\hline $\begin{array}{l}\text { Mean } \\
\text { absolute error }\end{array}$ & MAE $=\frac{1}{n} \sum_{i=1}^{n}\left|h_{o}-h_{s}\right|$ & 1.72 & 139 \\
\hline $\begin{array}{l}\text { Root mean } \\
\text { square error }\end{array}$ & $\mathrm{RMSE}=\sqrt{\frac{1}{n} \sum_{i=1}^{n}\left(h_{o}-h_{s}\right)_{i}^{2}}$ & 2.24 & 184 \\
\hline $\begin{array}{l}\text { Model } \\
\text { efficiency }\end{array}$ & $\mathrm{MEF}=\frac{\sum_{i=1}^{n}\left(h_{o}-h_{s}\right)^{2}}{\sum_{i=1}^{n}\left(h_{o}-\bar{h}\right)^{2}}$ & 0.98 & 0.91 \\
\hline$\left(R^{2}\right)$ & & 0.89 & 0.87 \\
\hline
\end{tabular}

the pumping will increase according to the historical trend. As in Punjab province of Pakistan, about 1.20 million tube wells have been installed and increasing at 5.5\% annually [44]. This indicated that the amount of withdrawal from aquifer may increase from $3738 \mathrm{MCM}$ in year 2012 to $6008 \mathrm{MCM}$ in year 2030 whereas recharge would be about $2664 \mathrm{MCM}$ according to historic trend. In Scenario II, one of the water management options for the study area was proposed. In the upper part of the study area (Pindi Bhatiyan-Safdrabad) where groundwater has good quality, the rate of groundwater abstraction was increased and recharge through an irrigation system was decreased by $35 \%$, while in the lower part, where groundwater has poor quality, the groundwater abstraction was decreased and recharge through an irrigation system was increased by the same rate.

\section{Results and Discussion}

3.1. Calibration and Validation of Models. The degree of fit between model simulations and field measurements was quantified by statistical means (Table 2) and all parameters were found in acceptable range. The minus sign of mean error (ME) represented that the model simulated values were higher than the measured head. The calibration criterion for hydraulic head is root mean squire error (RMSE) which is less than or equal to $10 \%$ of head variation within the aquifer being modeled [45] and the same criterion is also followed in groundwater TDS. The head in the aquifer within the study area varies from approximately 145 to $205 \mathrm{~m}$, resulting in an acceptable RMSE of $6 \mathrm{~m}$ or less. Similarly, the TDS in the aquifer at selected points are varied from 384 to $3768 \mathrm{mg} / \mathrm{L}$, resulting in an acceptable RMSE of $339 \mathrm{mg} / \mathrm{L}$ or less. Anderson and Woesner [46] and Moriasi et al. [47] reported that the RMSE is generally considered the best calibration indicator. Asghar et al. [48] said that the negative value of Model Efficiency (MEF) indicates the high variability between the observed and simulated values. A zero value of MEF indicates a poor simulation. If the model simulated values exactly match the observed value then the MEF = 1. So, all the values showed a good fit between measured

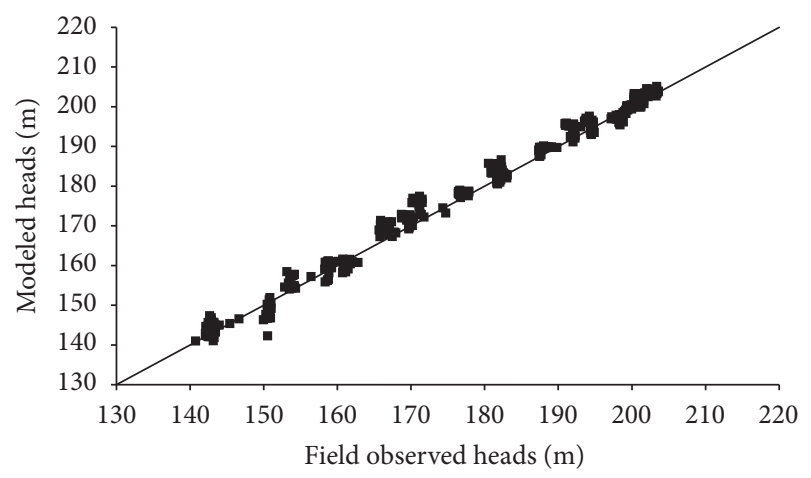

Figure 6: Scattergram of measured versus modeled heads in MODLOW.

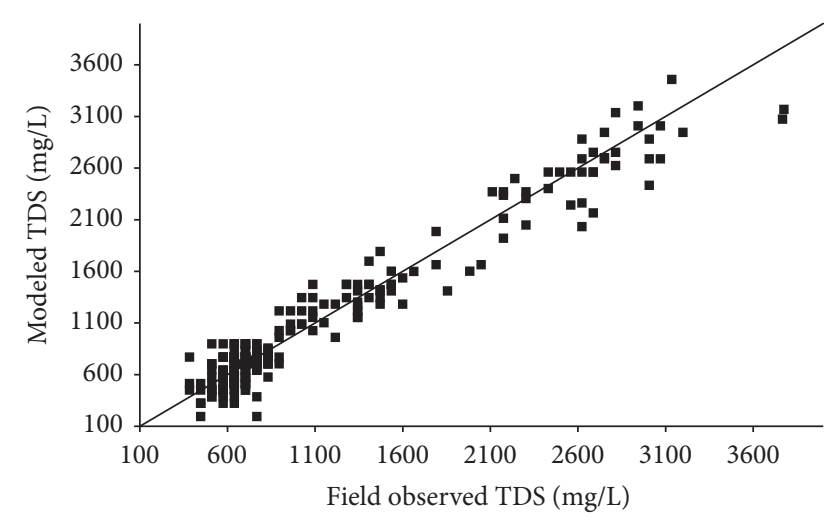

FIGURE 7: Scattergram of measured versus modeled TDS in MT3D.

and simulated values. The average coefficient of determination $\left(R^{2}\right)$ for the selected piezometers for calibration and validation period was calculated as 0.89 and 0.87 (Figures 6 and 7) for MODFLOW and MT3D models, respectively, which indicated a close agreement between the calculated and measured groundwater head. Hagos [49] calibrated PMWIN model for Raya valley, Ethiopia, with respect to groundwater level. The values of ME, MAE, and RMSE of calibrated results were $-1.4 \mathrm{~m}, 7.8 \mathrm{~m}$, and $10.7 \mathrm{~m}$, respectively, with coefficient of determination of 0.97 and reported to be satisfactory.

3.2. Sensitivity Analysis. The sensitivity analysis showed that recharge and transmissivity of the aquifer were most sensitive parameters. The factors of $0.5,0.8,0.9,1.1,1.2,1.3$, and 1.5 were multiplied with the calibrated values of recharge and transmissivity. The resulting hydraulic heads were then compared with the observed heads and RMSE was calculated for each parameter. It was observed that the minor variation in transmissivity or recharge rate values affected the hydraulic head impressively. The resulting plots of sensitivity showed the nonlinear response to recharge and transmissivity (Figures 8 and 9).

3.3. Predicted Groundwater Level. The contour lines of predicted groundwater level for the year 2030 under Scenario I 


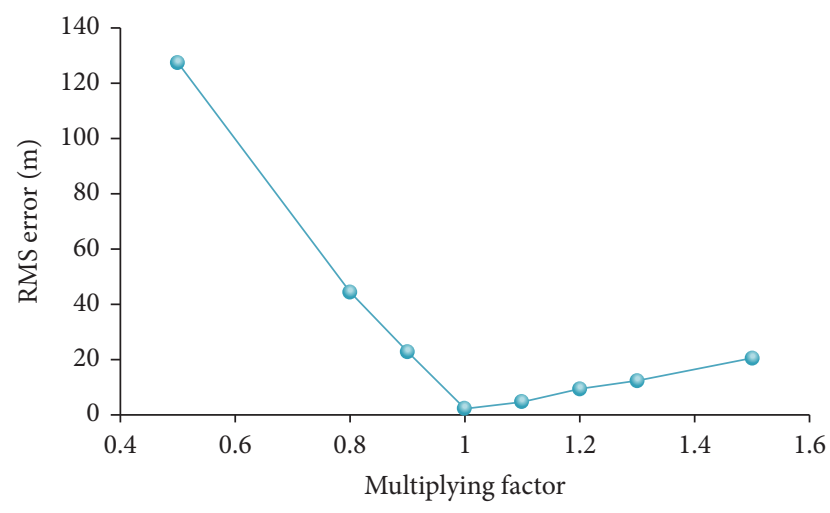

FIGURE 8: Sensitivity analysis with respect to recharge.

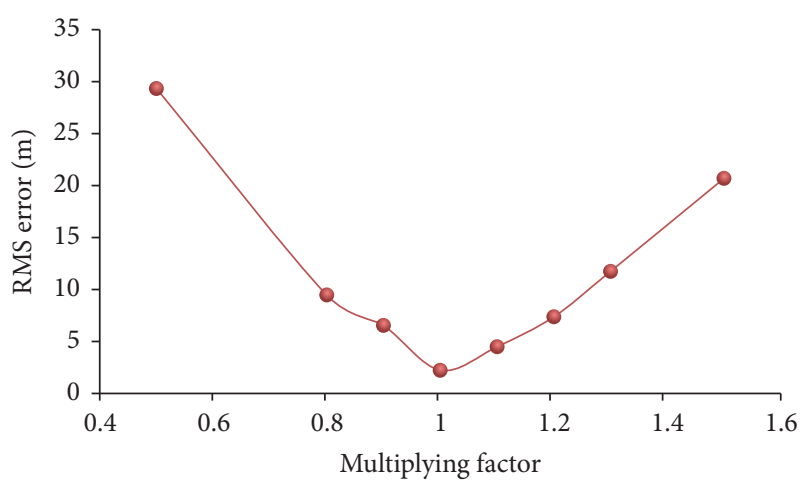

FIGURE 9: Sensitivity analysis with respect to transmissivity.

and Scenario II are presented in Figures 10 and 11, respectively. Under Scenario I, the maximum depletion in groundwater level would be up to $18 \mathrm{~m}$ near Bhawana, where irrigation is mainly dependent upon groundwater. Qureshi et al. [7] reported that the depletion of groundwater was more pronounced in uncommand areas of the Punjab, where surfacewater supplies were constrained and agriculture was heavily dependent on groundwater. In the upper part of the study area, comparatively less depletion ( $2 \mathrm{~m}$ on the average) in the groundwater level was observed. Under Scenario II, decline of groundwater level by 3-4 $\mathrm{m}$ was observed. In comparison with Scenario I the difference is of about 1-2 $\mathrm{m}$, which is not too high. In the lower part near Jhang and TT Singh, there would be a rise of groundwater level by up to $2 \mathrm{~m}$ (Figure 11). Shifting of canal water supplies would have good effect for replenishing groundwater.

The depletion of groundwater level has direct and indirect impact on pumping cost. Kori et al. [17] discussed that the decline in groundwater level would increase the abstraction cost. The construction cost of a deep electric tube well $(>20 \mathrm{~m}$ ) was reported as US $\$ 5000$ as compared to US $\$ 1000$ for a shallow $(<6 \mathrm{~m})$ tube well. Obrien et al. [50] reported that cost of pumping $103 \mathrm{~m}^{3}$ water was US $\$ 8.61$ and US $\$ 18.78$ for $31 \mathrm{~m}$ and $91 \mathrm{~m}$ lift, respectively. Basharat [51] reported that cost of pumping per cubic meter of groundwater increased about 3.5 times because the depth of water table dropped from 6 to $21 \mathrm{~m}$. Qureshi et al. [52] calculated that the installation
TABLE 3: Dispersivity values used in MT3D.

\begin{tabular}{lcc}
\hline Parameter & Used value & $\begin{array}{c}\text { Possible range and } \\
\text { source }\end{array}$ \\
\hline $\begin{array}{l}\text { Longitudinal } \\
\text { dispersivity (m) }\end{array}$ & 5.06 & $\begin{array}{c}3-15.24[42] \\
1-10[54] \\
1.89-5[53]\end{array}$ \\
\hline $\begin{array}{l}\text { Horizontal transverse } \\
\text { dispersivity (m) }\end{array}$ & 0.45 & $0.01-10[42,55]$ \\
$\begin{array}{l}\text { Vertical transverse } \\
\text { dispersivity (m) }\end{array}$ & 0.015 & $0.01-10[42,55]$ \\
\hline
\end{tabular}

TABLE 4: Value of parameters for dispersive transport.

\begin{tabular}{lccc}
\hline Layer number & TRPT $(-)$ & TRPV & DMCOEF \\
\hline 1 & 0.09 & 0.003 & 0.1 \\
2 & 0.09 & 0.003 & 0.1 \\
3 & 0.09 & 0.003 & 0.1 \\
\hline
\end{tabular}

TRPT is the ratio of the horizontal transverse dispersivity to the longitudinal dispersivity; TRPV is the ratio of the vertical transverse dispersivity to the longitudinal dispersivity; DMCOEF is the effective molecular diffusion coefficient $\left[\mathrm{L}^{2} \mathrm{~T}^{-1}\right]$.

cost of private tube well in Pakistan was US $\$ 530$ for the areas where the water table depth was less than $6 \mathrm{~m}$ and it was US $\$ 3206$ for the areas with more than $24 \mathrm{~m}$ depth.

3.4. Transport of Salts. The value of longitudinal dispersivity was calculated as $5.06 \mathrm{~m}$ (Table 3). Ahmad [53] reported that the values of longitudinal dispersivity were between 1.89 and $5 \mathrm{~m}$ for the aquifer of the Indus Basin of Pakistan. Gelhar et al. [42] reviewed various researches and reported that the value of longitudinal dispersivity was between 3 and $15.24 \mathrm{~m}$, whereas Engesgaard et al. [54] reported the range of longitudinal dispersivity from 1 to $10 \mathrm{~m}$. The value of horizontal and vertical transverse dispersivity was found to be 0.45 and $0.015 \mathrm{~m}$, respectively, based on soil type and hydraulic conductivity [42]. Shieh et al. [55] concluded that the transverse (horizontal and vertical) dispersivity was between 0.01 and $10 \mathrm{~m}$. Narayan et al. [56] developed SUTRA, a solute transport model for the Lower Burdekin Delta, North Queensland, and found longitudinal dispersivity of $2.5 \mathrm{~m}$ and transverse dispersivity of $0.5 \mathrm{~m}$.

The dispersivity values used in the MT3D model are given in Table 4. The value of TRPT (ratio of the horizontal transverse dispersivity to the longitudinal dispersivity) and TRPV (ratio of the vertical transverse dispersivity to the longitudinal dispersivity) was 0.09 and 0.003 , respectively. The effective molecular diffusion coefficient (DMCOEF) describes the diffusive flux of a solute in water from an area of greater concentration towards an area where it is less concentrated. The molecular diffusion coefficient is generally very small and negligible compared to the mechanical dispersion, so it was $0.1[17,39]$. The value of Peclet number was found to be 494 . For such higher value of Peclet number, the solute transport is dominated by the advection, that is, the transport of solute due to bulk flow of water $[43,57]$. 


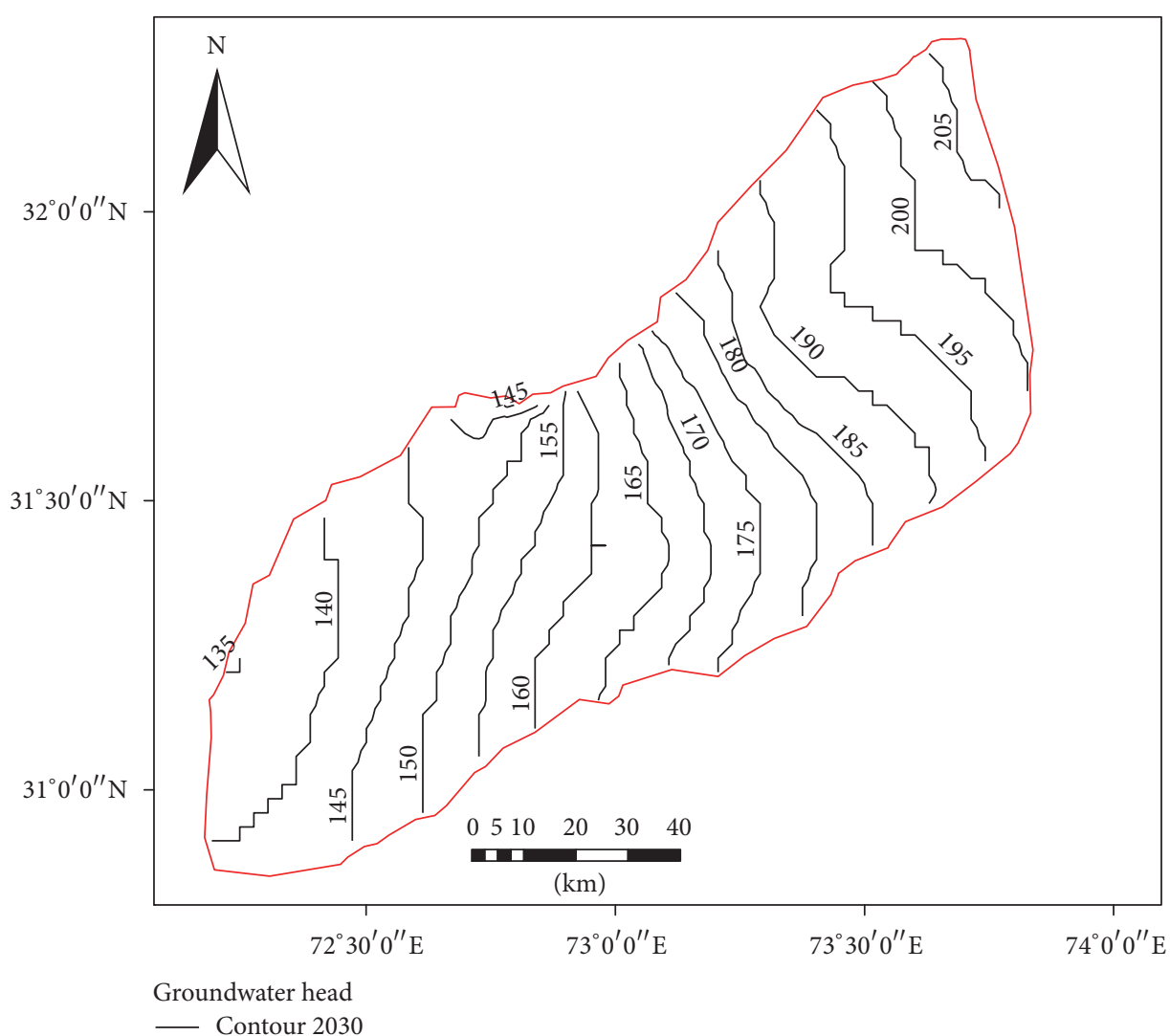

FIgURE 10: Predicted groundwater level in 2030 (Scenario I).

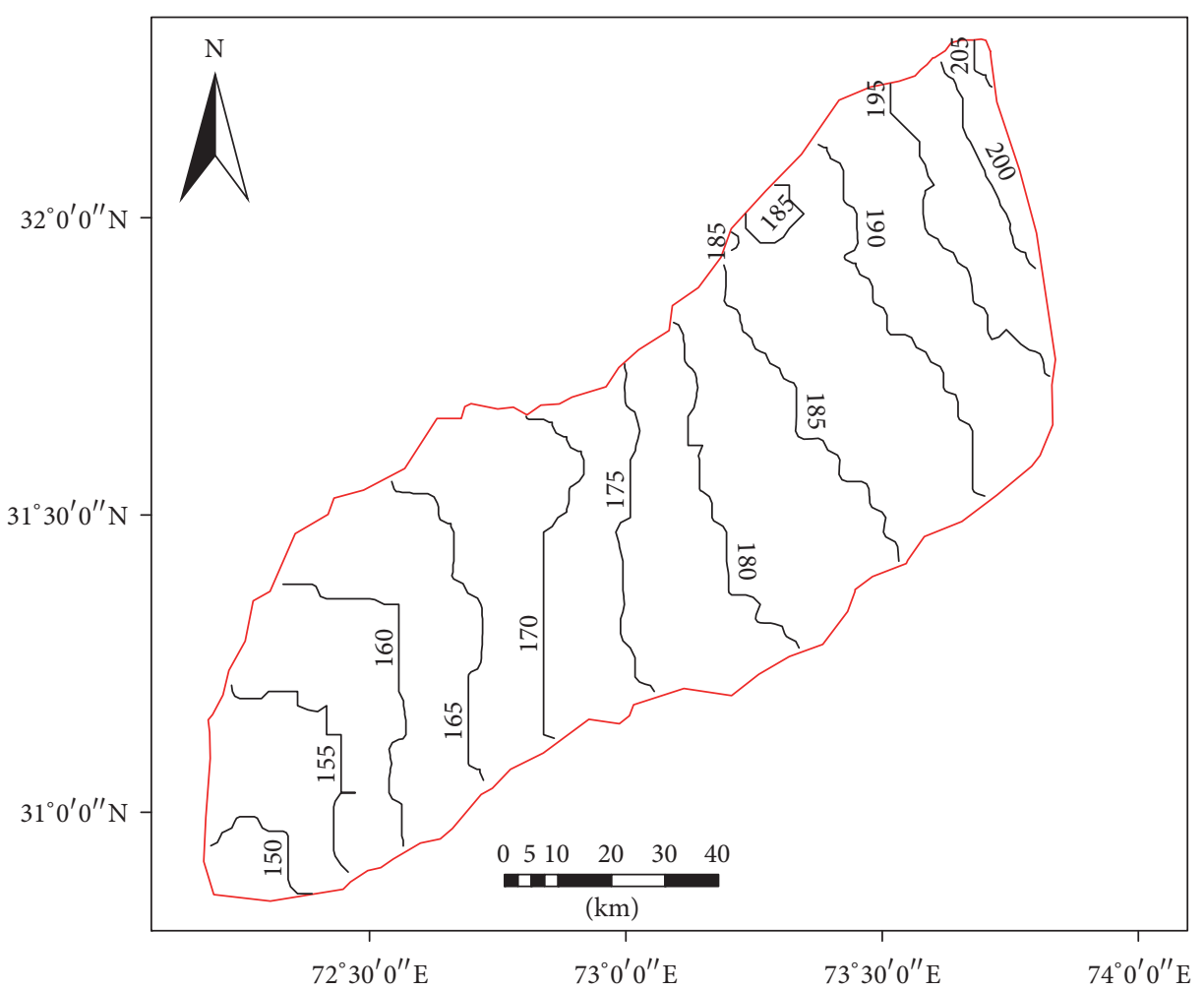

Groundwater head

— Contour 2030

FIgURe 11: Predicted groundwater level in 2030 (Scenario II). 


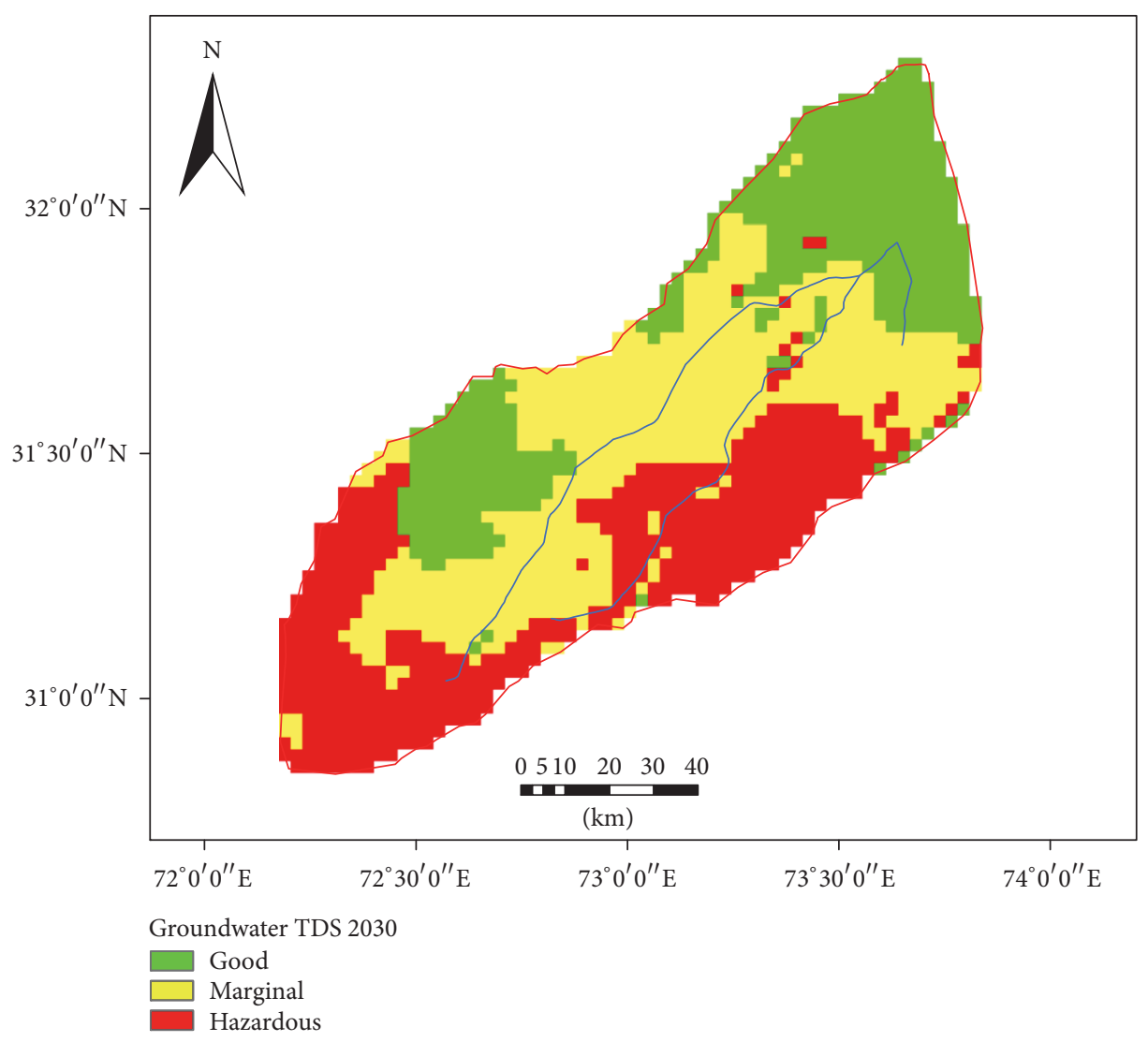

Figure 12: Predicted groundwater quality in year 2030 (Scenario I).

3.5. Predicted Groundwater Quality. Predicted variations in groundwater TDS under Scenario I up to year 2030 are presented in Figure 12. For the year 2030, the 28.95\% area will have good quality groundwater, $38.35 \%$ area will have marginal quality, and the remaining $32.71 \%$ area will have hazardous quality groundwater of the aquifer with TDS concentration of greater than $1000 \mathrm{mg} / \mathrm{L}$. The results showed that $21.40 \%$ good quality area will be converted from marginal into poor quality after 18 years. So, marginal and hazardous quality groundwater areas are expected to increase by 19.28 and $2.13 \%$, respectively. The area of hazardous quality water almost remained the same but its severance increased due to less recharge of fresh water than discharge. The change in groundwater TDS concentration under Scenario I up to year 2030 is shown in Figure 13.

The negative sign indicated the increase in groundwater TDS concentration and vice versa. The groundwater TDS of about $85 \%$ of the aquifer would increase up to $1500 \mathrm{mg} / \mathrm{L}$ and the remaining area up to $2500 \mathrm{mg} / \mathrm{L}$ located at southern part of the study area near Jhang and TT Singh. The groundwater quality of $<1 \%$ area would increase up to $140 \mathrm{mg} / \mathrm{L}$ near Hafizabad because of having relatively high potential of recharge irrigation network and rainfall. The predicted results revealed that groundwater quality of the northern part of the study area will not be affected with the increase in the pumping due to balance between discharge and recharge. The irrigation networks in that upstream area are well established and generally received more canal water than the allocated share $[50,51]$.

Simultaneously, the groundwater quality in middle and lower part will be affected severely by salinity due to imbalance between discharge and recharge of fresh water. The farmers of downstream areas received about $21 \%$ less canal water than designed discharge imposed farmers to use groundwater as a primary source [51, 52]. This abundant abstraction of groundwater is deteriorating the groundwater quality due to both horizontal and vertical saline intrusion $[58,59]$. Prinos [60] described the multiple pathways for saltwater intrusion into freshwater zone in Florida near the well field. Khan et al. [33] said that overpumping of groundwater from aquifer induced the lateral saltwater intrusion into the fresh groundwater area and the vertical upconing of the saline interface is resulting in degradation of aquifers. The farmers in the study area abstracted groundwater without any quality check. The continuous use of such poor quality water is causing secondary salinization and ultimately reduces crop productivity $[6,51]$. The groundwater quality results of Scenario I clearly indicated that an increase in the number of tube wells in the future could cause the problem of salinization; therefore, the groundwater regulation aimed at protecting the quality and quantity of groundwater resource must be implemented [61-63]. 
TABLE 5: Summary of groundwater TDS under Scenarios I and II.

\begin{tabular}{|c|c|c|c|c|c|c|c|}
\hline \multirow{3}{*}{ Scenario } & \multirow{3}{*}{ Year } & \multicolumn{6}{|c|}{ Groundwater quality } \\
\hline & & \multicolumn{2}{|c|}{ Good } & \multicolumn{2}{|c|}{ Marginal } & \multicolumn{2}{|c|}{ Hazardous } \\
\hline & & Area $\left(\mathrm{km}^{2}\right)$ & Area (\%) & Area $\left(\mathrm{km}^{2}\right)$ & Area (\%) & Area $\left(\mathrm{km}^{2}\right)$ & Area (\%) \\
\hline Current status & 2012 & 5829.27 & 50.35 & 2207.98 & 19.07 & 3538.75 & 30.58 \\
\hline I & 2030 & 3350.95 & 28.95 & 4438.92 & 38.35 & 3786.14 & 32.71 \\
\hline II & 2030 & 4083.51 & 35.27 & 5149.72 & 44.48 & 2342.76 & 20.23 \\
\hline
\end{tabular}

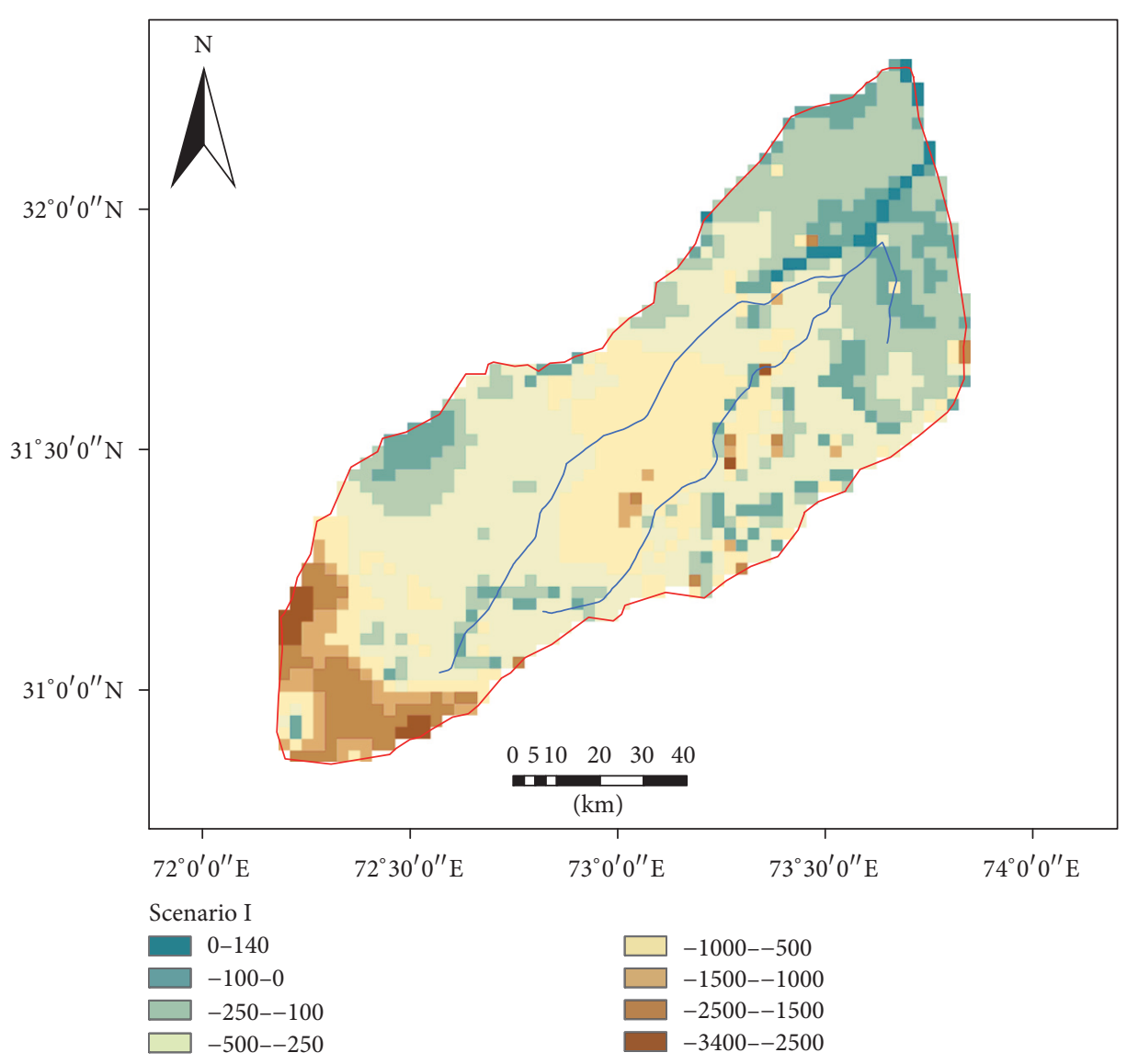

FIGURE 13: Change in groundwater TDS in the year 2030 (Scenario I).

The predicted results of the spatial variation of groundwater salinity up to year 2030, under Scenario II, are shown in Figure 14. It shows that $35.27 \%$ area of the aquifer will have good quality, $44.48 \%$ area will have marginal quality, and the remaining $20.23 \%$ area will have hazardous quality groundwater. The analysis of the groundwater quality results indicated that if the groundwater abstraction is increased by $35 \%$ and irrigation recharge is decreased by $35 \%$ in the upper part of the study, the overall increase in groundwater salinity will remain under the safe limit, while, in the lower part of the study area, if abstraction is decreased by $35 \%$ and irrigation recharge is increased by $35 \%$, there will be an improvement in groundwater quality up to $500 \mathrm{mg} / \mathrm{L}$ (Figure 15). Under Scenario II, the area under good and hazardous quality increased by 15.08 and $10.35 \%$, respectively, compared with current status.

The results of groundwater quality for Scenarios I and II are summarized in Table 5. The analysis of the model results of both scenarios up to year 2030 showed that $6.32 \%$ area has good quality water and $12.48 \%$ has less hazardous quality in Scenario II compared with Scenario I. In Scenario II, $6.13 \%$ more area is under marginal quality, possibly due to shifting of water quality from hazardous quality due to higher recharge from increased canal water supply in the lower part of study area. Hence the results of Scenario II revealed that the need of the hour is a need for a shift in surface irrigation water to the lower part of the study area to reduce groundwater salinity problems. This will also provide formers 


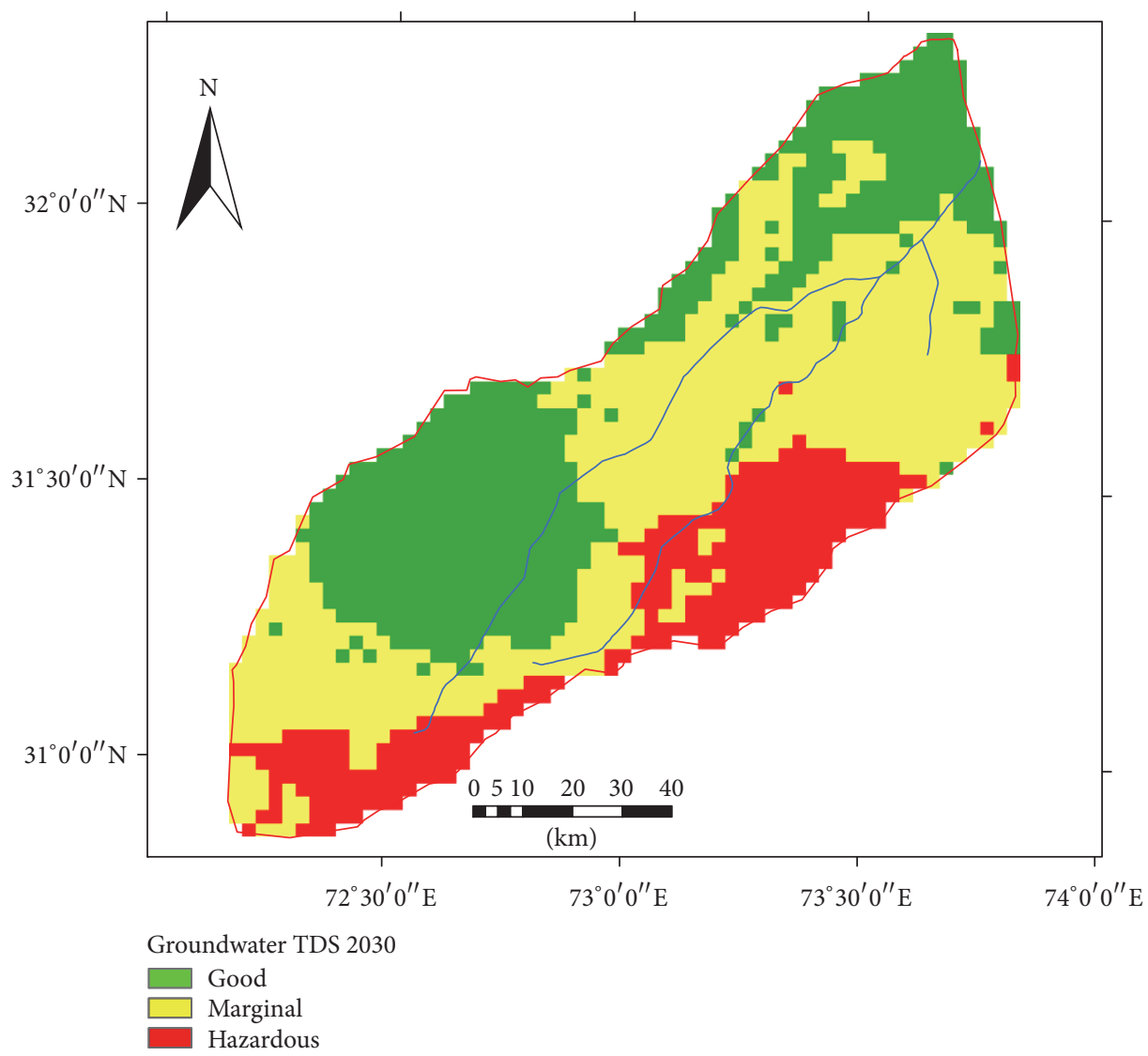

FIGURE 14: Predicted groundwater quality in the year 2030 (Scenario II).

with a way forward for conjunctive surface and groundwater irrigation technology for sustainable water management for this region and to avoid secondary salinization [59]. Foster and van Steenbergen [64] concluded that the evolution to more planned conjunctive use of groundwater and surfacewater resources offers great potential for increasing watersupply security in both irrigated agriculture and urban water supply across the developing world, especially on large alluvial plains which are often major centers of population and economic development. It was also reported that there are spontaneous conjunctive groundwater and surface-water use in Indian, Pakistani, Moroccan, and Argentinean irrigationcanal commands which have largely arisen due to inadequate surface-water supply to meet irrigation demand.

\section{Conclusions}

The MODFLOW and MT3D models were calibrated for the period of 2003-2007 and validated for the years 2008-2012 using the measured groundwater level and quality data, respectively, for regional groundwater management in Punjab province of Pakistan. The main conclusions drawn from this study were as follows:

(i) The surface soil textures are largely fine and moderately medium with good permeability properties. In general, the aquifers of the study area are unconfined. (ii) Almost half of the aquifer of the study area has marginal to hazardous quality of groundwater. A $30 \mathrm{~km}$ wide strip along the Chenab River had groundwater of good quality. It was also observed that, at a distance of $40 \mathrm{~km}$ away from the river, a $20 \mathrm{~km}$ wide strip of hazardous quality was found.

(iii) The volume of water withdrawn through tube wells increased by about 14\% from the years 2003 to 2012 and caused the rapid lowering of water table.

(iv) The predicted results of Scenario I revealed that the area good quality groundwater will reduce to $21.4 \%$, while marginal and areas hazardous quality water will increase as 19.28 and $2 \%$, respectively.

(v) The most affected areas will be found in the middle and lower parts of the study area such as Faisalabad, Jhang, Gujra, and TT Singh.

(vi) Under Scenario II, area of good quality groundwater will increase to $6.32 \%$ area and $12.48 \%$ area will possess less hazardous quality of groundwater.

These results indicated that the canal water supply should shift from good to poor quality groundwater region for proficient management of aquifer water. This can be achieved by regulating the surface-water supplies from irrigation headworks through irrigation department. It is also recommended 


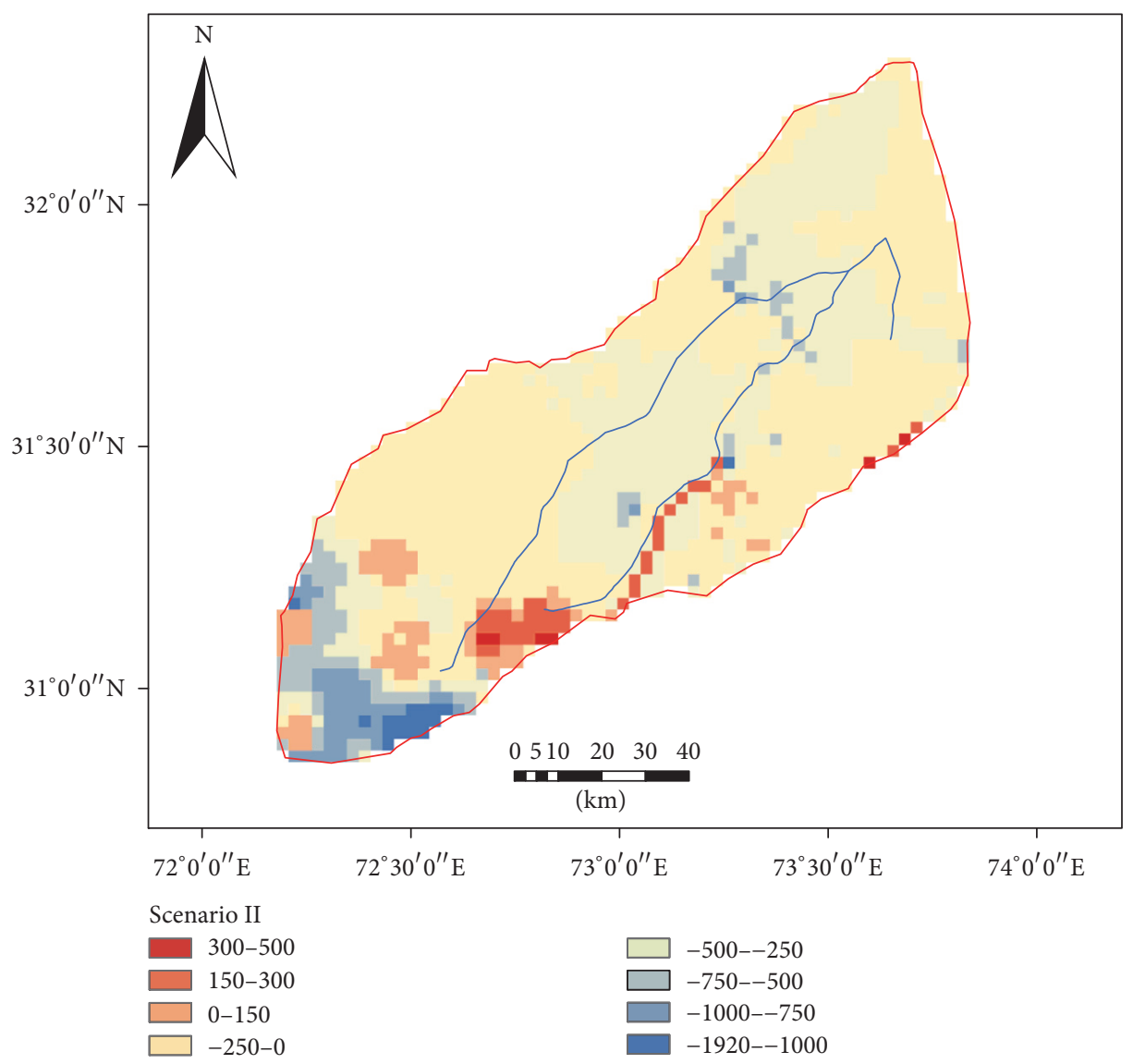

FIGURE 15: Change in groundwater TDS in the year 2030 (Scenario II).

that the detailed field survey is required to determine the exact advective and dispersive solute transport parameters for more accurate results of MT3D model.

\section{Conflicts of Interest}

The authors declared that there are no conflicts of interest regarding the publication of this paper.

\section{Acknowledgments}

The authors acknowledge the financial support from Higher Education Commission (HEC), Pakistan, under Ph.D. Indigenous Scholarship Program. They are also grateful to WAPDA, Pakistan Meteorology Department, and Department of Land and Reclamation, Faisalabad, for providing data to accomplish this research.

\section{References}

[1] Q. Javed, M. Arshad, A. Bakhsh, A. Shakoor, Z. A. Chatha, and I. Ahmad, "Redesigning of drip irrigation system using locally manufactured material to control pipe losses for orchard," Pakistan Journal of Life and Social Sciences, vol. 13, no. 1, pp. 1619, 2015.
[2] A. S. Mongat, M. Arshad, A. Bakhsh et al., "Design, installation and evaluation of solar drip irrigation system at mini dam command area," Pakistan Journal of Agricultural Sciences, vol. 52, no. 2, pp. 483-490, 2015.

[3] M. S. Shafique, F. D. Johnson, and E. W. Jackson, "Sulfurous acid generator: A technology to mitigate drought conditions," in National Symposium on Drought and Water Resources in Pakistan, Lahore, Pakistan, 2002.

[4] M. Arshad, A. Shakoor, I. Ahmad, and M. Ahmad, "Hydraulic transmissivity determination for the groundwater exploration using vertical electric sounding method in comparison to the traditional methods," Pakistan Journal of Agricultural Sciences, vol. 50, no. 3, pp. 487-492, 2013.

[5] M. N. Bhutta and L. K. Smedema, "One hundred years of waterlogging and salinity control in the indus valley, Pakistan: A historical review," Irrigation and Drainage, vol. 56, no. 1, pp. S81-590, 2007.

[6] A. Shakoor, M. Arshad, A. Bakhsh, and R. Ahmed, "Gis based assessment and delineation of groundwater quality zones and its impact on agricultural productivity," Pakistan Journal of Agricultural Sciences, vol. 52, no. 3, pp. 837-843, 2015.

[7] A. S. Qureshi, P. G. McCornick, M. Qadir, and Z. Aslam, "Managing salinity and waterlogging in the Indus Basin of Pakistan," Agricultural Water Management, vol. 95, no. 1, pp. 110, 2008.

[8] A. L. Qureshi, B. K. Lashari, S. M. Kori, and G. A. Lashari, "Hydro-salinity behavior of shallow groundwater aquifer 
underlain by salty groundwater in Sindh Pakistan," in Fifteenth international water technology conference, IWTC-15, Alexandria, Egypt, 2011.

[9] T. Shah, "Groundwater governance and irrigated agriculture," Tec Background Papers No. 19. Global Water Partnership Technical Committee (TEC), 2014.

[10] A. S. Qureshi, P. G. McCornick, A. Sarwar, and B. R. Sharma, "Challenges and Prospects of Sustainable Groundwater Management in the Indus Basin, Pakistan," Water Resources Management, vol. 24, no. 8, pp. 1551-1569, 2010.

[11] H. Farid, Z. Mahmood-Khan, A. Ali, M. Mubeen, and M. Anjum, "Site-Specific Aquifer Characterization and Identification of Potential Groundwater Areas in Pakistan," Polish Journal of Environmental Studies, vol. 26, no. 1, pp. 17-27, 2017.

[12] A. Bakhsh and Q. A. Awan, Water Issues in Pakistan And Their Remedies. In, National Symposium on Drought And Water Resources in Pakistan, Cewre, university of engineering and technology Lahore, Pakistan, 2002.

[13] M. Irfan, M. Arshad, A. Shakoor, and L. Anjum, "Impact of irrigation management practices and water quality on maize production and water use efficiency," Journal of Animal and Plant Sciences, vol. 24, no. 5, pp. 1518-1524, 2014.

[14] G. Haider and G. Hussain, "Problems associated with ground water utilization and their management in scarp areas. In proceedings of the workshop on membrane biophysics and salt tolerance in plants, Faisalabad," Pakistan, 2001.

[15] V. Ezin, R. Delapena, and A. Ahanchede, "Physiological and agronomical criteria for screening tomato genotypes for tolerance to salinity," Electronic Journal of Environmental, Agricultural and Food Chemistry, vol. 9, no. 10, p. 1641, 2010.

[16] A. Ashraf and Z. Ahmad, "Regional groundwater flow modelling of Upper Chaj Doab of Indus Basin, Pakistan using finite element model (Feflow) and geoinformatics," Geophysical Journal International, vol. 173, no. 1, pp. 17-24, 2008.

[17] S. M. Kori, A. L. Qureshi, B. K. Lashari, and N. A. Memon, "Optimum strategies of groundwater pumping regime under scavanger tubewells in lower indus basin, sindh," Pakistan. Inter. Water tech. J. (IWTJ, vol. 3, no. 3, p. 138, 2013.

[18] R. Lalehzari, S. H. Tabatabaei, and M. Kholghi, "Hydrodynamic coefficients estimation and aquifer simulation using PMWIN model," in Fourteenth International Water Technology Conference (IWTC-14), Cairo, Egypt, 2010.

[19] C. P. Kumar, "Groundwater Modelling Software - Capabilities and Limitations," IOSR Journal of Environmental Science, Toxicology and Food Technology, vol. 1, no. 2, pp. 46-57, 2012.

[20] M. Arshad, N. Ahmad, and M. Usman, "Simulating seepage from branch canal under crop, land and water relationships," International Journal of Agriculture and Biology, vol. 11, article 529, 2009.

[21] C. Moeck, A. Affolter, D. Radny, A. Auckenthaler, P. Huggenberger, and M. Schirmer, "Improved water resource management using three dimensional groundwater modelling for a highly complex environmental," in Proceedings of the InEGU General Assembly Conference Abstracts, vol. 19, 19056, 2017.

[22] T. Gebreyohannes, F. de Smedt, K. Walraevens et al., "Regional groundwater flow modeling of the Geba basin, northern Ethiopia," Hydrogeology Journal, pp. 1-17, 2017.

[23] N. Rahmawati, J.-F. Vuillaume, and I. L. S. Purnama, "Salt intrusion in coastal and lowland areas of semarang city," Journal of Hydrology, vol. 494, pp. 146-159, 2013.
[24] S. Carretero, J. Rapaglia, H. Bokuniewicz, and E. Kruse, "Impact of sea-level rise on saltwater intrusion length into the coastal aquifer, Partido de La Costa, Argentina," Continental Shelf Research, vol. 61-62, pp. 62-70, 2013.

[25] W. A. Abu-el-Shar and R. I. Hatamleh, "Using Modflow and $\mathrm{mt} 3 \mathrm{~d}$ groundwater flow and transport models as a management tool for the Azraq groundwater system," Jordan Journal of Civil Engineering, vol. 1, no. 2, p. 153, 2007.

[26] A. Asoka, T. Gleeson, Y. Wada, and V. Mishra, "Relative contribution of monsoon precipitation and pumping to changes in groundwater storage in India," Nature Geoscience, vol. 10, no. 2, pp. 109-117, 2017.

[27] I. Galitskaya, K. R. Mohan, A. K. Krishna et al., "Assessment of soil and Groundwater Contamination by Heavy Metals and Metalloids in Russian and Indian Megacities," Procedia Earth and Planetary Science, vol. 17, pp. 674-677, 2017.

[28] J. B. Kambale, D. K. Singh, and A. Sarangi, "Impact of climate change on groundwater recharge in a semi-arid region of northern India," Applied Ecology and Environmental Research, vol. 15, no. 1, pp. 335-362, 2017.

[29] T. Abdullah and K. Morteza, "Groundwater modeling by MODFLOW model In Toyserkan aquifer and evaluation of hydrogeological state under present and future conditions," Water Engineering, vol. 9, no. 31, pp. 45-60, 2017.

[30] V. Durand, V. Léonardi, G. de Marsily, and P. Lachassagne, "Quantification of the specific yield in a two-layer hard-rock aquifer model," Journal of Hydrology, vol. 551, pp. 328-339, 2017.

[31] WAPDA, Hydrogeological data of Rechna Doab. Volume-I, publication No. 25. Project planning organization (N.Z) Water and Power Development Authority (WAPDA), 27-E/I Gulberg III, Lahore, 1978.

[32] A. N. Al-Fatlawi, The application of the mathematical model (MODFLOW) to simulate the behavior of groundwater flow in Umm er Radhuma unconfined aquifer. Euphrates Journal of Agriculture Science, vol 3, article 1, no. 1, 2011.

[33] S. Khan, T. Rana, H. F. Gabriel, and M. K. Ullah, "Hydrogeologic assessment of escalating groundwater exploitation in the Indus Basin, Pakistan," Hydrogeology Journal, vol. 16, no. 8, pp. 16351654, 2008.

[34] G. Schoups, C. L. Addams, and S. M. Gorelick, "Multi-objective calibration of a surface water-groundwater flow model in an irrigated agricultural region: Yaqui Valley, Sonora, Mexico," Hydrology and Earth System Sciences, vol. 9, no. 5, pp. 549-568, 2005.

[35] W. A. Jehangir, A. S. Qureshi, and N. Ali, Conjunctive water management in the Rechna doab: an overview of resources and issues. Working paper 48. International water management institute Lahore, Pakistan, 13, 1, 2002.

[36] M. D. Ahmad, Estimation of net groundwater use in irrigated river basins using geo-information techniques: a case study in Rechna doab, Pakistan (Ph.D. Thesis), Wageningen University, Wageningen, 2002.

[37] M. Arshad, Contribution of irrigation conveyance system components to the recharge potential in Rechna Doab under lined and unlined options. PhD Thesis, Faculty of Agricultural Engineering and Technology, University of Agriculture, FaisalabadPakistan, 2004.

[38] C. Zheng, MT3D-A modular three-dimensional transport model for simulation of advection, dispersion and chemical reactions of contaminants in groundwater systems. Report to the u.s. Environmental protection agency, ADA, Oklahoma, 1990. 
[39] W. H. Chiang and W. Kinzelbach, "Processing Modflow: a simulation system for modeling groundwater flow and pollution. User's manual,' User's manual. U.S. Department of the interior, U.S. Geological survey, 1998.

[40] P. A. Domenico and F. W. Schwartz, Physical and chemical hydrogeology, John Wiley, New York, USA, 2nd edition, 1990.

[41] CSIRO, "Investigation conjunctive water management options using a dynamic surface-groundwater modeling approach: a case study of Rechna doab. Commonwealth scientific and industrial research organization (CSIRO), land and water," Technical report 35/03, IWMI, 2003.

[42] L. W. Gelhar, C. Welty, and K. R. Rehfeldt, "A critical review of data on field-scale dispersion in aquifers," Water Resources Research, vol. 28, no. 7, pp. 1955-1974, 1992.

[43] M. Huysmans and A. Dassargues, "Review of the use of Péclet numbers to determine the relative importance of advection and diffusion in low permeability environments," Hydrogeology Journal, vol. 13, no. 5-6, pp. 895-904, 2005.

[44] PES. Pakistan economic survey 2008-09, Agriculture, Table 107, PP 171-172. Federal bureau of statistics, statistics division, ministry of economic affairs and statistics, govt. Of Pakistan, Islamabad, Pakistan, 2009.

[45] M.-S. Tsou, S. P. Perkins, X. Zhan, D. O. Whittemore, and L. Zheng, "Inverse approaches with lithologic information for a regional groundwater system in southwest Kansas," Journal of Hydrology, vol. 318, no. 1-4, pp. 292-300, 2006.

[46] M. P. Anderson and W. W. Woesner, Applied Groundwater Modeling: Simulation of Flow And Advective Transport, Academic press, San Diego, Calif, USA, 1992.

[47] D. N. Moriasi, J. G. Arnold, M. W. Van Liew, R. L. Bingner, R. D. Harmel, and T. L. Veith, "Model evaluation guidelines for systematic quantification of accuracy in watershed simulations," Transactions of the ASABE, vol. 50, no. 3, pp. 885-900, 2007.

[48] M. N. Asghar, S. A. Prathapar, and M. S. Shafique, "Extracting relatively-fresh groundwater from aquifers underlain by salty groundwater," Agricultural Water Management, vol. 52, no. 2, pp. 119-137, 2002.

[49] M. A. Hagos, "Groundwater flow modeling assisted by gis and rs techniques (raya valley- ethiopia)," M.Sc. Thesis in international institutes for geo-information science and earth observation Enschede, 2010.

[50] D. M. Obrien, T. J. Dumler, and D. H. Rogers, "Irrigation capital requirements and energy costs," in Farm Management Guide, MF-836, pp. 1-4, Kansas State University., 2011.

[51] M. Basharat, "Spatial and temporal appraisal of groundwater depth and quality in LBDC command-issues and options," Pakistan Journal of Engineering and Applied Sciences, vol. 11, article 14, 2012.

[52] A. S. Qureshi, T. Shah, and M. Akhtar, The groundwater economy of Pakistan, Working Paper 64. Lahore, Pakistan: International Water Management Institute (IWMI), vol. 64, pp. 1-31, 2003.

[53] N. Ahmad, Groundwater resources of Pakistan, 61-b/2, Gulberg III, Lahore, Pakistan, 1974.

[54] P. Engesgaard, K. H. Jensen, J. Molson, E. O. Frind, and H. Olsen, "Large-scale dispersion in a sandy aquifer: Simulation of subsurface transport of environmental tritium," Water Resources Research, vol. 32, no. 11, pp. 3253-3266, 1996.

[55] H.-Y. Shieh, J.-S. Chen, C.-N. Lin, W.-K. Wang, and C.-W. Liu, "Development of an artificial neural network model for determination of longitudinal and transverse dispersivities in a convergent flow tracer test," Journal of Hydrology, vol. 391, no. 3-4, pp. 367-376, 2010.
[56] K. A. Narayan, C. Schleeberger, P. B. Charlesworth, and K. L. Bristow, Effects of groundwater pumping on saltwater intrusion in the lower burdekin delta, north queensland, vol. 201, article 224, Modelling and simulation society of Australia and Newzealand Inc., 2002.

[57] A. Fiori, "Finite Peclet extensions of Dagan's solutions to transport in anisotropic heterogeneous formations," Water Resources Research, vol. 32, no. 1, pp. 193-198, 1996.

[58] S. Asghar, "Farming system analysis of irrigated farms in Faisalabad, Pakistan," Thesis in natural resources management, school of environment, resources and development, Asian Institute of Technology, Thailand, 2014.

[59] D. Mekonnen, A. Siddiqi, and C. Ringler, "Drivers of groundwater use and technical efficiency of groundwater, canal water, and conjunctive use in Pakistan's Indus Basin Irrigation System," International Journal of Water Resources Development, vol. 32, no. 3, pp. 459-476, 2016.

[60] S. T. Prinos, "Saltwater intrusion monitoring in Florida. Special Issue: Status of Florida's Groundwater Resources," Florida Scientist, vol. 79, no. 4, 2016.

[61] A. S. Qureshi, "Improving food security and livelihood resilience through groundwater management in Pakistan," Global Advanced Research Journal of Agricultural Science, vol. 4, article 687, no. 10, 2015.

[62] A. S. Qureshi, "Water management in the Indus basin in Pakistan: Challenges and opportunities," Mountain Research and Development, vol. 31, no. 3, pp. 252-260, 2011.

[63] E. C. Dogrul, C. F. Brush, and T. N. Kadir, "Groundwater modeling in support ofwater resources management and planning under complex climate, regulatory, and economic stresses," Water (Switzerland), vol. 8, no. 12, article no. 592, 2016.

[64] S. Foster and F. V. van Steenbergen, "Conjunctive groundwater use: A 'lost opportunity' for water management in the developing world?" Hydrogeology Journal, vol. 19, no. 5, pp. 959-962, 2011. 

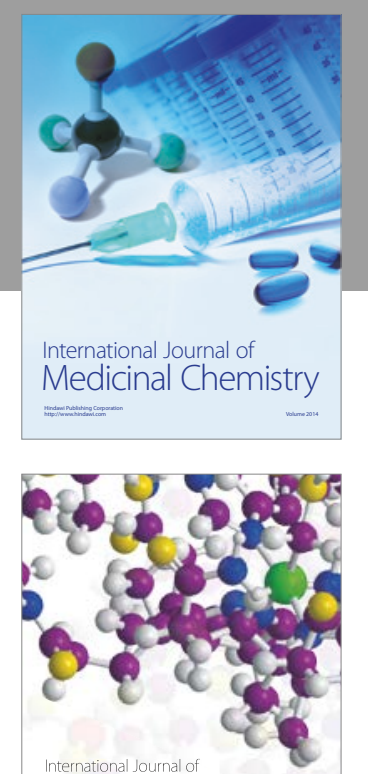

Carbohydrate Chemistry

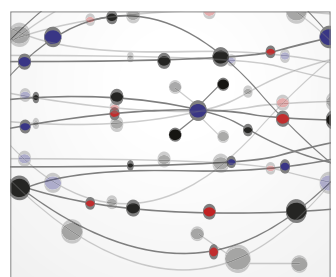

The Scientific World Journal
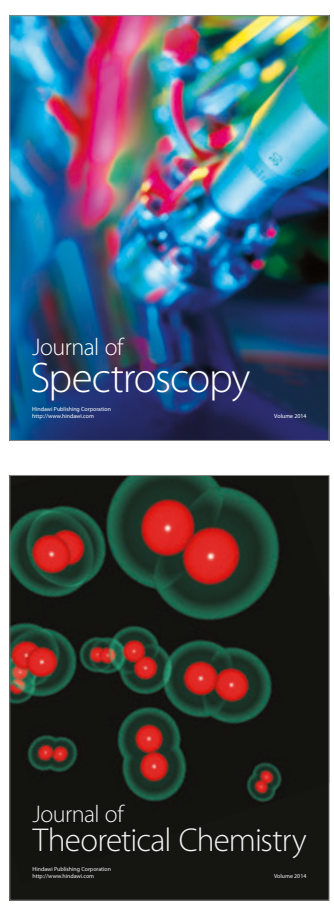
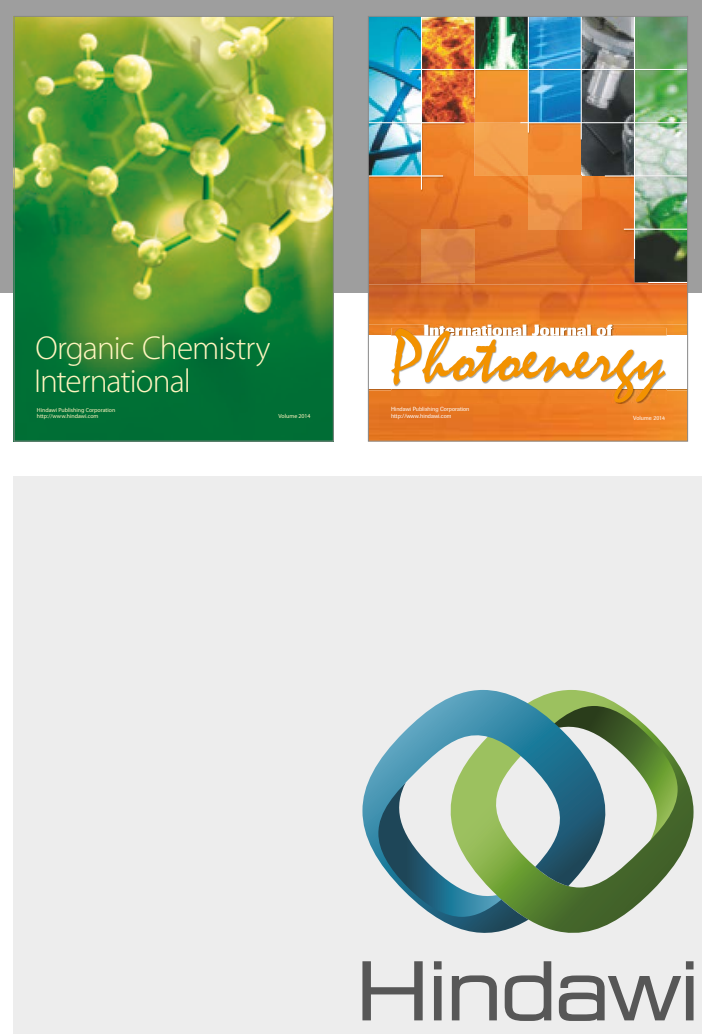

Submit your manuscripts at

https://www.hindawi.com

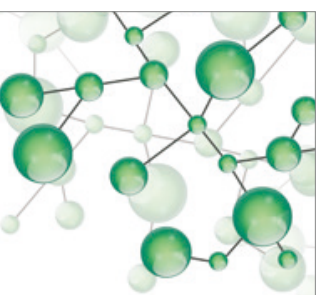

International Journal of

Inorganic Chemistry

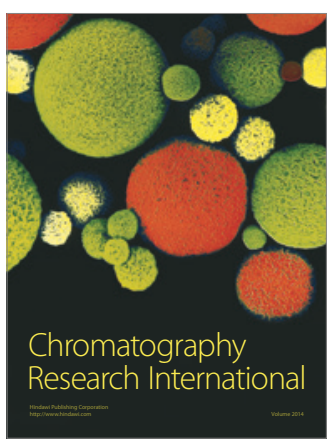

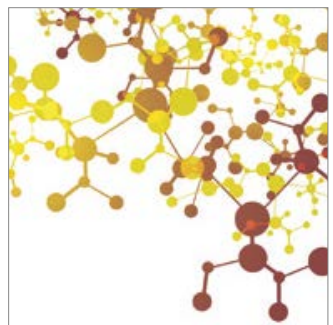

Applied Chemistry
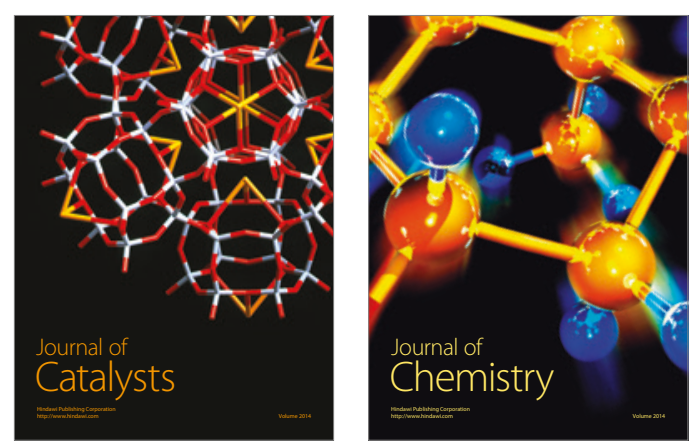
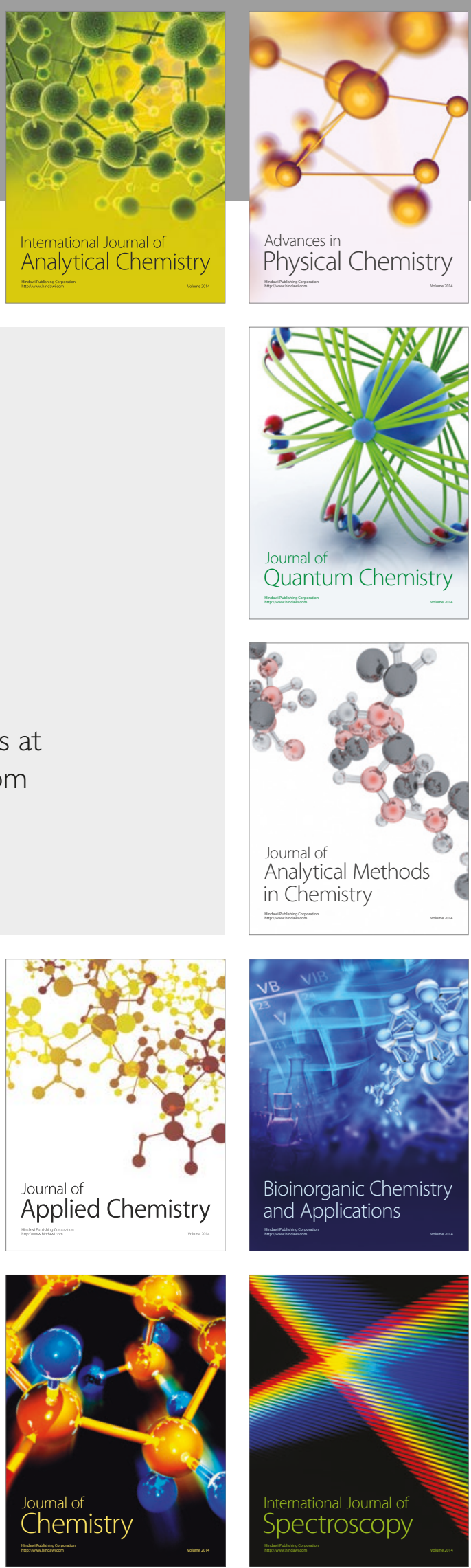